Article

\title{
Flash Flood and Extreme Rainfall Forecast through One-Way Coupling of WRF-SMAP Models: Natural Hazards in Rio de Janeiro State
}

\author{
Priscila da Cunha Luz Barcellos *(D) and Marcio Cataldi
}

Post-Graduate Program in Civil Engineering-Management, Production and Environment, Federal Fluminense University-UFF, Niterói, Rio de Janeiro 24210-240, Brazil; marcio.cataldi@gmail.com

* Correspondence: luz.priscila@gmail.com

Received: 3 July 2020; Accepted: 4 August 2020; Published: 7 August 2020

\begin{abstract}
Flash floods and extreme rains are destructive phenomena and difficult to forecast. In 2011, the mountainous region of Rio de Janeiro state suffered one of the largest natural hazards in Brazil, affecting more than 300,000 people, leaving more than 900 dead. This article simulates this natural hazard through Quantitative Precipitation Forecasting (QPF) and streamflow forecast ensemble, using 18 combinations of parameterizations between cumulus, microphysics, surface layer, planetary boundary layer, land surface and lateral contour conditions of the Weather Research and Forecasting (WRF) Model, coupling to the Soil Moisture Accounting Procedure (SMAP) hydrological model, seeking to find the best set of parametrizations for the forecasting of extreme events in the region. The results showed rainfall and streamflow forecast were underestimated by the models, reaching an error of $57.4 \%$ to QPF and $24.6 \%$ error to streamflow, and part of these errors are related to the lack of skill of the atmospheric model in predicting the intensity and the spatial-temporal distribution of rainfall. These results bring to light the limitations of numerical weather prediction, possibly due to the lack of initiatives involving the adaptation of empirical constants, intrinsic in the parametrization models, to the specific atmospheric conditions of each region of the country.
\end{abstract}

Keywords: hydrometeorology; WRF; SMAP; flash flood; natural hazards; extreme rainfall quantitative precipitation forecasting; parameterizations

\section{Introduction}

In January 2011, the mountainous region of the State of Rio de Janeiro, Brazil, was devastated as a result of continuous and intense rain leading to heavy landslides and flash floods. This event is considered the most intense natural hazards in the country in recent years, with more than 900 deaths and 300,000 people affected [1,2].

Events of this magnitude are challenging for hydrometeorological forecasts [3], assuring the importance of developing studies of scientific tools that may assist the government agencies while aiming to prevent and minimize possible consequences of these events.

Concerning flash floods, structural and non-structural measures are applied worldwide to prevent disasters [4-6], with a higher emphasis on non-structural methods as mainly structural methods are expensive and do not provide a $100 \%$ flood protection [7].

Inserted as a non-structural measure, hydrometeorological early warning systems can be a central tool for decision making [8-12] through numerical modeling techniques that may predict and anticipate flash floods.

Flash floods are phenomena initiated by heavy rainfall, therefore, predicting them is necessary to use hydrological modeling coupled with atmospheric modeling. Both must be well adapted and 
calibrated for the study region, allowing the forecast of the phenomena with a sufficient degree of confidence to sustain its credibility for the population, as they are the ones who will receive the alerts and leave their homes when applicable.

Hydrological models coupled with different types of precipitation inputs are used worldwide for predicting flash floods in early warning systems $[13,14]$, and many authors pointed out that errors in flood forecasting are associated with uncertainties and the lack of skill in Quantitative Precipitation Forecasting (QPF), which serve as input for the hydrological model [15]. For the United States region, Looper and Vieux [14] compared the forecasting skill of the hydrological model distributed in Texas using two types of precipitation inputs: data from radar and rain gauges and only with data from rain gauges, and the results highlighted the importance of precipitation data in the results of the hydrological model, where the inputs that used radar and rain gauge data led to better skill for flood forecasting than those that only used rain gauge data. Tao and Barros [16] showed that the flow predictions of the hydrological model were, in some regions, an overestimated or underestimated of in response to overestimating or underestimating the precipitation forecasts of the Weather Research and Forecasting (WRF) model during the study of the Tropical Storm Fay, 2008 over the Southern passage the Appalachian Mountains in North Carolina.

In Haiti, Shamir et al. [17] showed that the WRF model underestimated precipitation during the passage of Hurricane Tomas and propagated the errors for the flow forecast. In Italy, Senatori and Mendicino [18] simulated the hydrological and atmospheric coupling using the WRF-Hydro model with fully coupled flows, showing that the exchange of flows between the atmosphere and the water body and the flow and precipitation forecasts have better skill when using fully coupled models. In Taiwan, Shih et al. [19] pointed out that the hydrological model was able to predict the sign of the occurrence of the flood using the precipitation inputs of the WRF model, but they stressed that to the peak time and peak stages from the observations could not be obtained. In Spain, Amengual et al. [20] downscaled the ensemble of the European Centre for Medium-Range Weather Forecasts (ECMWF) global model, with 51 members, in the regional WRF model, and coupled the outputs to the hydrological model, showing that small errors generated by the predicted precipitation of the WRF model have an important impact on the flow outcomes.

Fredj and Givati [21], in Israel, simulated the flood forecast for two winters, 2012 and 2013, comparing outputs that used the precipitation of the atmospheric model WRF and the fully coupled model WRF-Hydro, and the results indicated that the simulated precipitation by WRF-Hydro had better skill than the forecast of precipitation of the WRF model, mainly for convective cells. Li et al. [22] studied the impact of precipitation inputs from the WRF model on the hydrological model in southern China and showed that the model overestimates rainfall in the watershed and increases this overestimation in the $48 \mathrm{~h}$ and $72 \mathrm{~h}$ forecasts.

Tao and Barros [16] described that future advances in flood forecasting are limited to Quantitative Precipitation Estimation (QPE) and QPF, with the spatial resolution necessary to solve the dynamics of precipitation and its interactions with surface, subsoil, and terrestrial systems in mountainous regions, for example.

QPF is one of the main challenges in atmospheric sciences studies, especially because of the synergy between the complex physical, dynamic, and thermodynamic processes that occur within the atmosphere. Precipitation forecasts by numerical weather prediction derive from the simulation of parameterizations in atmospheric processes that are related to convection and stratified clouds, the assimilation of large-scale waves interactions between atmospheric elements below the scale of cloud microphysics, as well as the cover information on land use and topography of the simulated area [23].

In this context, many researchers are focused on choosing a set of parameterizations in atmospheric modeling that can provide the best representation of precipitation for a given location and worldwide.

Among the several numerical weather prediction models used in the world, only used the atmospheric model Advanced Research Weather Research and Forecasting Model (ARW-WRF), we can 
mention the efforts of some authors. Jankov et al. [24] simulated five precipitation events that occurred in the winter of 2005/2006 in California using 4 different microphysical options schemes: Lin, WSM6, Thompson, and Schultz, with 3-km grid spacing in the ARW-WRF model, to simulate the convective cell structure and examine the schemes' ability to predict bright band from non-bright band precipitation regimes. The numerical simulations were compared with observed data, and the results showed that the model tended to overestimate the duration and intensity of the low-level winds, and the precipitation, mainly in the case of bright band events.

Yuan et al. [25] studied the importance of downscaling through the sixteen WRF ensemble downscaling forecasts, with different parameterization sets, and fifteen Climate Forecast System (CFS) ensemble prediction for the winter season between 1982 and 2008 in China. The results showed that WRF ensemble downscaling forecasts had better skill concerning the forecast of precipitation than the CFS model, and highlighted as the best set for the forecast of seasonal precipitation the one that used the schemes: Thompson microphysics, Grell cumulus, Noah land surface scheme, and Rapid Radiative Transfer Model for General circulation models (RRTMG) radiation.

Mooney et al. [26] studied the climate in eight sub-regions in Europe between 1990 and 1995 using the WRF to downscale interim model ECMWF Re-Analysis (ERA-Interim) data and simulating twelve combinations of parametric schemes. Two longwave radiation schemes, two land surface models, two microphysics schemes, and two planetary boundary layer schemes were tested, and the outputs of the variables surface air temperatures, precipitation, and mean sea level pressure compared with observed data. The analyses showed that simulated precipitation proved to be a major problem in the study, with low temporal correlation coefficients with observations and biases of up to $100 \%$ at certain times of the year. The authors pointed out that precipitation was sensitive to changes in longwave radiation and microphysics schemes in the summer and was not sensitive to changes in planetary boundary layer schemes, highlighting the importance of carefully choosing an optimal combination of parametric schemes for each region when the WRF model is used.

Kala et al. [27] tested the sensitivity of the WRF model with different input data and different parameterizations for similar over a $10-\mathrm{km}$ grid domain in the southwest of Western Australia to improve the climate forecast simulations for agriculture. The results showed that precipitation was sensitive to changes in the radiation scheme and that changes in the cumulus scheme or more complex microphysics did not strongly influence precipitation simulations in the region. The Kain-Fritsch and Betts-Miller-Janjic cumulus scheme did not present significant differences in the precipitation forecast for the studied region, and the authors emphasized that the model systematically underestimated the precipitation on the coast, which can be related to possible errors due to un-resolved topography.

Ratnam et al. [28] carried out 17 experiments with the WRF model forced with the ERA-Interim reanalysis data and $30-\mathrm{km}$ grid to find the best parametric set for precipitation forecasting in the Indian summer monsoon for the years 1982 to 2013. The authors highlighted the importance of studying different combinations of parametrizations schemes and the results showed that the set that used the parametrizations Kain-Fritsch cumulus scheme, a radiation package with the Dudhia shortwave and Rapid Radiative Transfer Model longwave schemes, the Yonsei State University planetary boundary layer scheme, the WRF Single-Moment 3-class microphysics scheme, the revised MM5 Monin-Obukhov surface layer scheme, and the Unified Noah land surface model achieved the best skill for simulating the precipitation in the region.

Attada et al. [29] investigated the sensitivity of three cumulus parameterization schemes, Kain-Fritsch, Betts-Miller-Janjic, and Grell-Freitas, for the forecast of rain during winter in the period between 2001 and 2016 in the Arabian Peninsula and compared it with observed data Tropical Rain Measurement System (TRMM) and reanalysis data sets. The authors evaluated the distributions of circulation, temperature, humidity, and clouds to understand the dynamic and thermodynamic responses of the model precipitation through two-way nested domains with respective horizontal resolutions of $15 \mathrm{~km}$ and $5 \mathrm{~km}$. The precipitation results highlighted that the Kain-Fritsch scheme 
obtained the best skill to capture precipitation in the region, although with slightly underestimated results and, on the contrary, the Grell-Freitas scheme obtained the lowest skill.

For forecasts in the mountainous region of Rio de Janeiro, besides the topographical features, it is even more difficult to predict extreme rainfall due to the influence of transient meteorological systems in higher latitudes, cold fronts, and other phenomena typical of equatorial latitudes, such as convective storms that results from daytime warming.

Cavalcanti et al. [30] adapted soil parameters of the Soil Moisture Accounting Procedure (SMAP) hydrological model for the Rio Grande watershed in the mountainous region of Rio de Janeiro and tested the predictability of the model for the event of January 2011 using the rain gauge as an input. Although the streamflow forecast of the SMAP model overestimated the flood wave with a relative error of $53 \%$ compared to the observed data, the results were promising to predict the occurrence of the flood wave. It is worth mentioning that all the rain gauges were torn off by flash floods during the event, thus the data described as "observed" during the peak of the flood is an estimation of the peak reconstructed by the National Water Agency (Agência Nacional de Águas-ANA).

This article aims to simulate an extreme event of a practically operational environment through an ensemble forecast of precipitation and streamflow that utilizes different sets of parameterizations of the WRF atmospheric model with its QPF coupled to the SMAP hydrological model, previously calibrated for the small watershed in the municipality of Bom Jardim by Cavalcanti et al. [30].

\section{Data and Method}

\subsection{Study Area}

The mountainous region of Rio de Janeiro is formed by 14 municipalities and it is located in the central portion of the state with an average altitude ranging between $300 \mathrm{~m}$ and about $2800 \mathrm{~m}$ (Figure 1). It can be characterized by embedded valleys and high slopes, with river watersheds in this region conducive to flash floods that reach high speeds with a destructive potential [31].

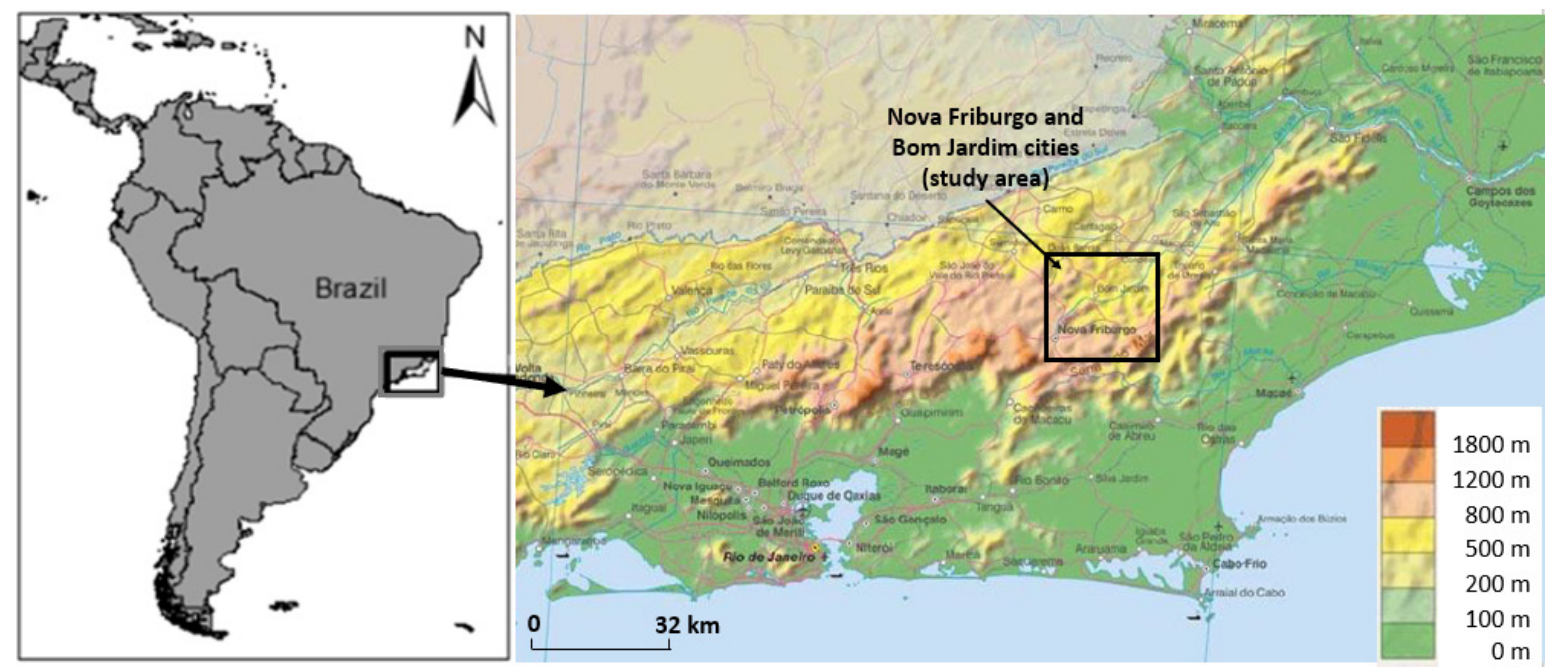

Figure 1. The topography of the mountainous region of Rio de Janeiro State and study area (Nova Friburgo and Bom Jardim cities) (Adapted from [32]).

This research studied the Rio Grande watershed, located upstream of the city of Bom Jardim, inside of the city Nova Friburgo. In its entirety, the Rio Grande watershed has a perimeter of $194 \mathrm{~km}$, an area of $996 \mathrm{~km}^{2}$, an average slope between $21.78^{\circ}$ and $69.97^{\circ}$, and a maximum altitude level ranging between $2.281 \mathrm{~m}$ and $400 \mathrm{~m}$ [33]. This research only considered the portion of the watershed located within the fluviometric station of Bom Jardim of the National Water Agency (Agência Nacional de Águas-ANA), composing an area of $538.96 \mathrm{~km}^{2}$ (Figure 2). 


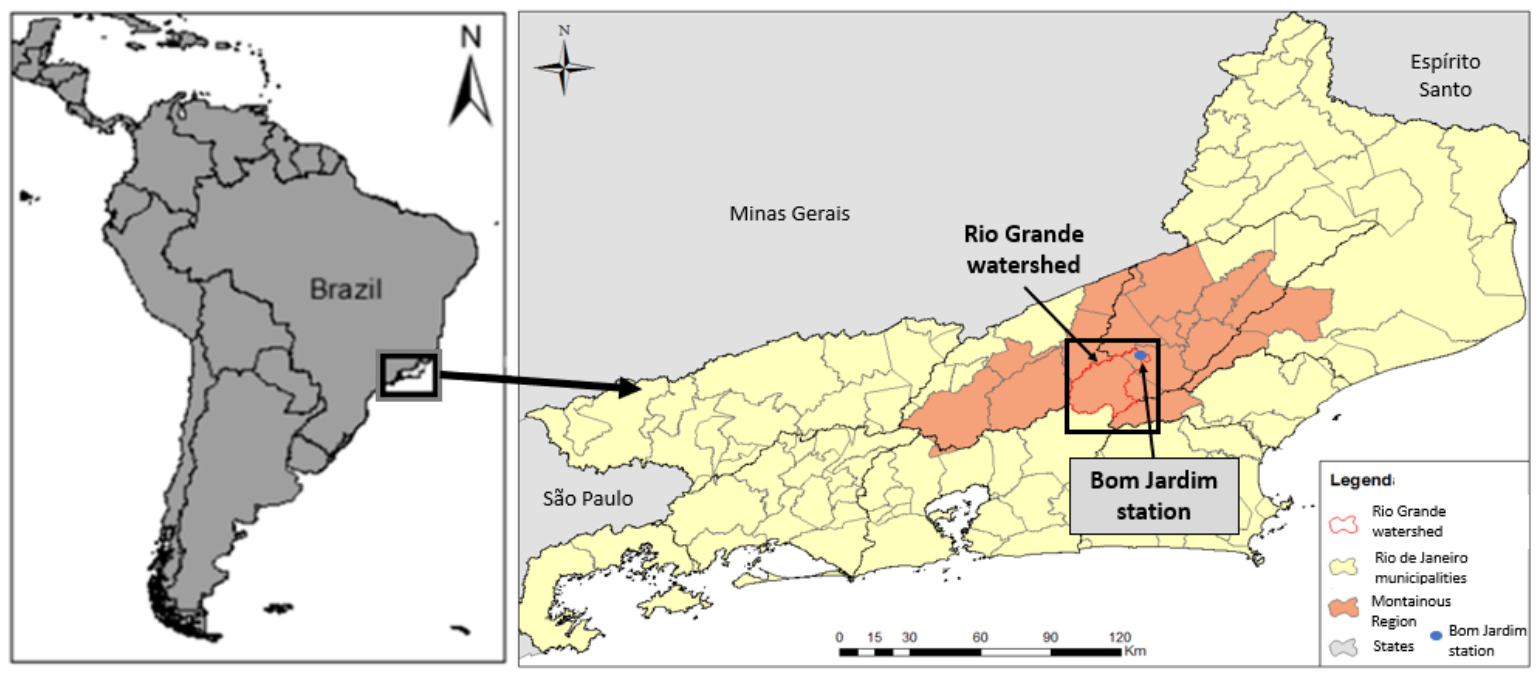

Figure 2. Rio Grande watershed and Bom Jardim station locations in the mountainous region of Rio de Janeiro State.

\subsection{The Natural Hazard of 2011}

In 2011, the mountainous region of Rio de Janeiro in Brazil was affected by one of the largest natural hazards ever recorded in the country in recent years. Convective storms developed within the South Atlantic Convergence Zone (SACZ) on 12 January led to accumulated precipitation that exceeded $70 \%$ of the monthly average in just one night.

Intense and continuous rain led to the occurrence of landslides and flash floods devastating entire neighborhoods (Figure 3), directly affecting more than 300,000 people and causing more than 900 fatal victims, leading the municipalities of the mountainous region to declare a state of public calamity $[1,2]$.
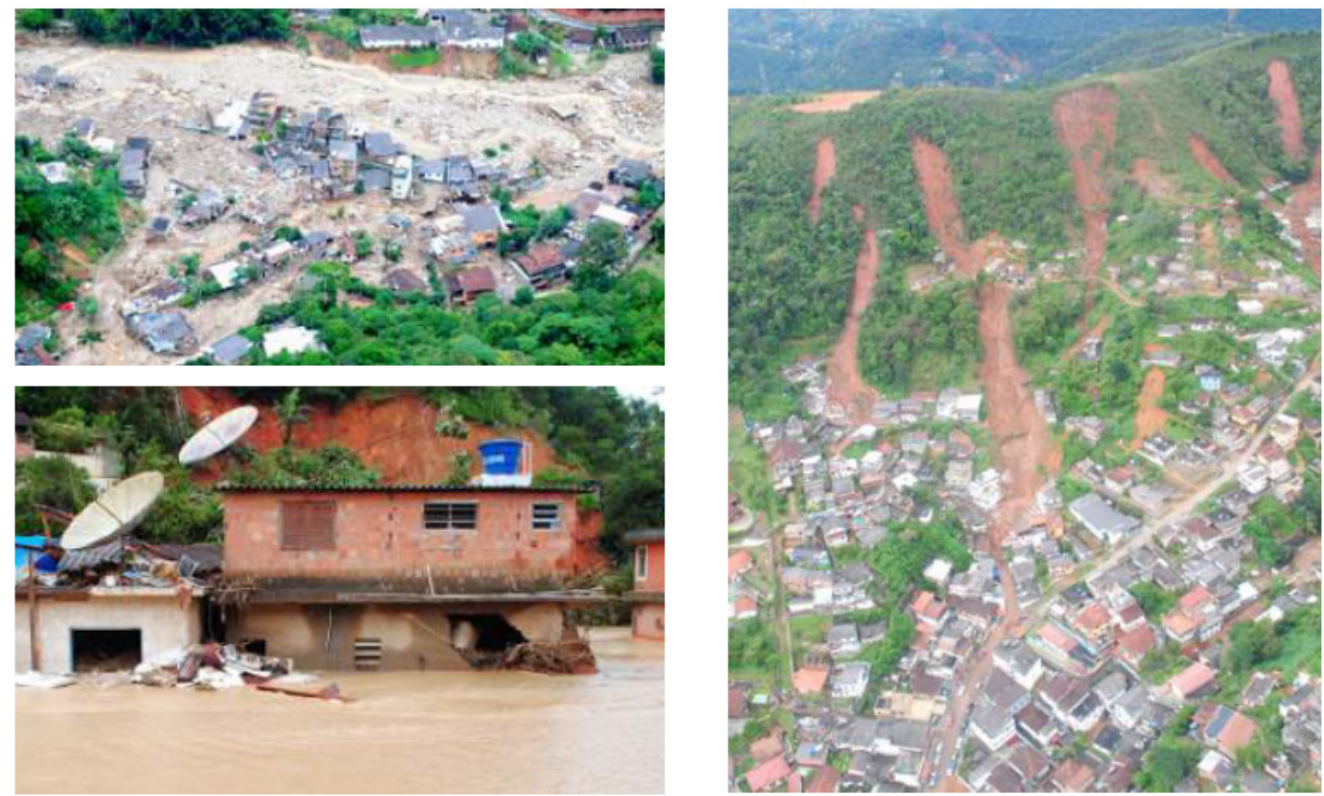

Figure 3. Magnitude of the destruction of the natural hazards in the mountainous region of the State of Rio de Janeiro (Source: [1]).

It is estimated that economic losses associated to the disaster exceeded $\mathrm{R} \$ 4.78$ billion, which affected the socio-economic fields and transportation, water supply, health, trade, and sanitation in the municipalities of Nova Friburgo, São José do Vale do Rio Preto, Bom Jardim, Areal, Petrópolis, Sumidouro, and Teresópolis [1]. 
This event started with rainfall of weak intensity on the morning of 11 January 2011. At the end of the day, convective cells fed on heat and moisture from the day warming developed strongly. According to data of rain gauge and water level stations from the State Institute of the Environment (Instituto Estadual do Ambiente-INEA), the most intense rain began at approximately 9 pm, persisting considered strong to moderate for 8 uninterrupted hours in the early hours of the 12th.

The accumulated rainfall on that night in Nova Friburgo city registered by rain gauges carried out with landslides and flash floods was $166 \mathrm{~mm}$, accounted by a rain gauge of Nova Friburgo from the National Institute of Meteorology (Instituto Nacional de Meteorologia-INMET). Records were superior to $185 \mathrm{~mm}$ in the Pico Caledonia, $272 \mathrm{~mm}$ in Olaria, $213 \mathrm{~mm}$ in Praça do Suspiro, and reached $296 \mathrm{~mm}$ in the Ypu from the INEA automatic hydrometeorological stations.

According to the seven rain gauges and one hydrological station of the National Water Agency, used in this study and that record the data every $24 \mathrm{~h}$, the observed rainfall in the watershed varied with the accumulated between 20 and $180 \mathrm{~mm} / 24 \mathrm{~h}$ on 11 January, and Figure 4 shows the interpolation of the observed rainfall data for this day. It is worth highlighting that all rain gauges were destroyed and carried away by the flash flood that occurred during the natural hazard on the dawn of 12 January and, therefore, it was not possible to evaluate the observed rainfall after $00 \mathrm{Z}$ of that day.

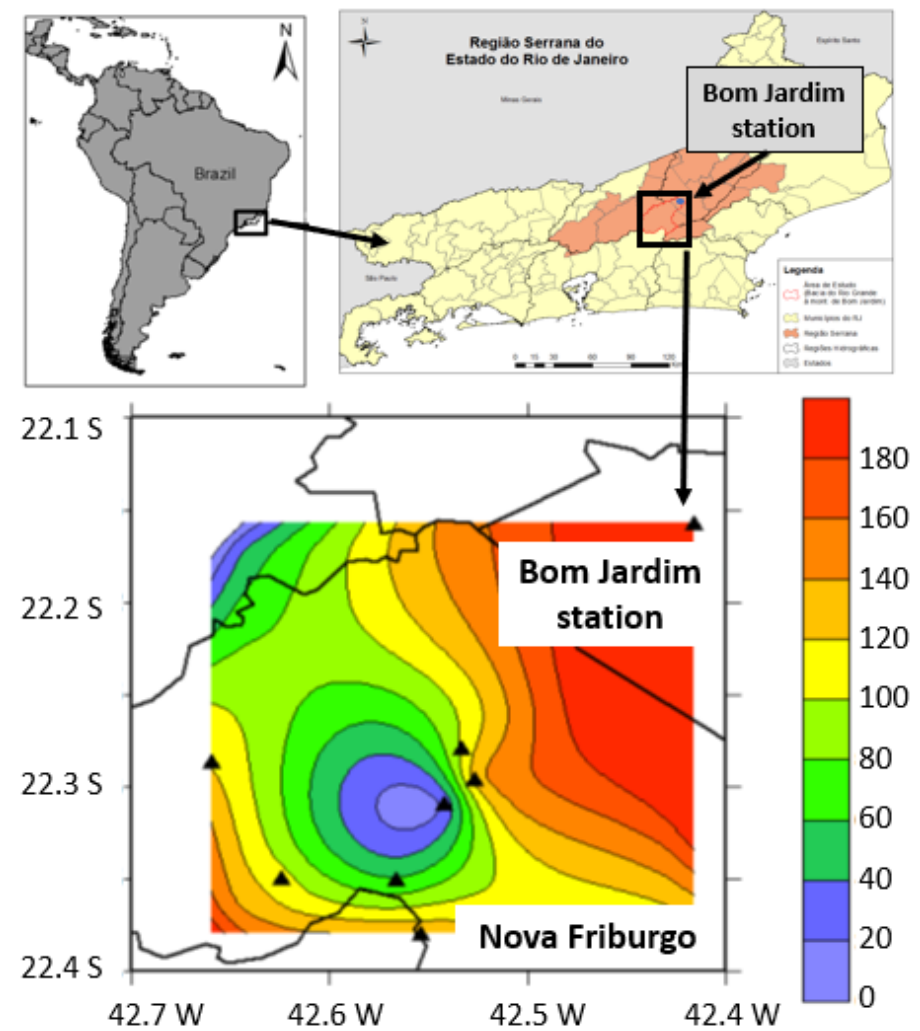

Figure 4. Location of 7 rain gauges (black triangle), a hydrological station of Bom Jardim (black triangle), and interpolation of the observed rainfall on 11 January $(\mathrm{mm} / 24 \mathrm{~h})$.

In Figure 4, it is possible to observe that, due to the interpolation of the rainfall occurred on 11 January in the neighborhood of Bom Jardim station, the accumulated values exceeded $180 \mathrm{~mm} / 24 \mathrm{~h}$ (red) as well as in the region located southwest of the figure corresponding the southwestern part of the studied watershed. The lowest accumulated rainfalls were located in the central part of the figure, also corresponding to the central region of the watershed, registering a minimum of $20 \mathrm{~mm} / 24 \mathrm{~h}$ (blue) and increasing in intensity radially towards the southwest and northeast regions of the figure. 


\subsection{Precipitation: WRF Model}

The first objective of this research was to identify a set of parameterizations of the WRF model [34] that could better predict the extreme rainfall that occurred during the event in the mountainous region of Rio de Janeiro in January 2011.

This study used the version of WRF-ARW 3.8, with 3 nested grids one-way, the cartographic projection of Mercator, and the central point of the grid localized in the Nova Friburgo city, with coordinates of $22.122^{\circ} \mathrm{S}$ and $042.592^{\circ} \mathrm{W}$.

The horizontal spatial resolution of each grid was $9 \mathrm{~km}, 3 \mathrm{~km}$, and $1 \mathrm{~km}$, according to Figure 5 . The time step was adjusted to $54 \mathrm{~s}$, and 27 vertical levels of sigma vertical coordinate were considered.

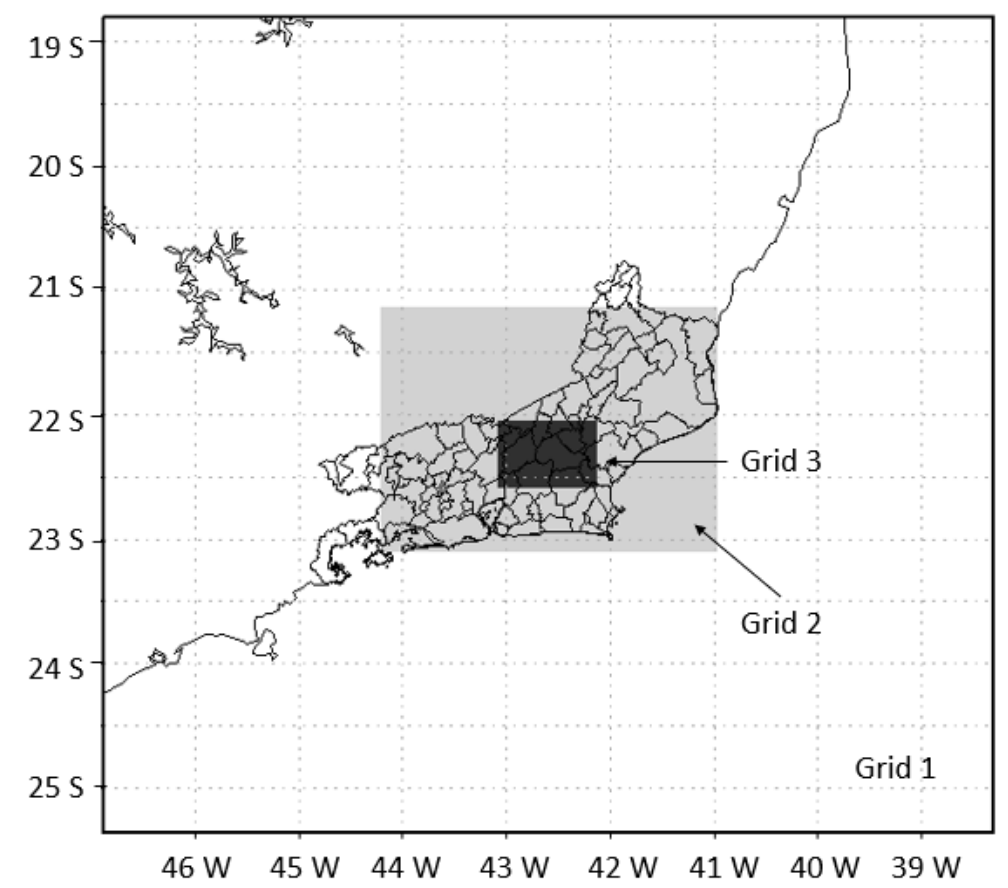

Figure 5. Nested grids with horizontal spatial resolution with $9 \mathrm{~km}$ (Grid 1), 3 km (Grid 2), and $1 \mathrm{~km}$ (Grid 3) in the Weather Research and Forecasting (WRF) model.

The initial and boundary conditions were obtained from the predictions of the Global Forecast System (GFS) model developed by the National Centers for Environmental Prediction (NCEP) [35].

The GFS model is a coupled model, with four separate model components for atmosphere, ocean, land, and sea ice, which work together to provide an estimated picture of weather conditions. This dataset runs four times daily out to $192 \mathrm{~h}$ with a $0.5^{\circ}$ horizontal resolution and a 3-h temporal resolution. This study used GFS forecasts initialized from $00 \mathrm{Z}$ on 11 January 2011, with forecast output produced every $3 \mathrm{~h}$ for $72 \mathrm{~h}$.

Parameterizations of longwave and shortwave radiation were maintained constant (were used Dudhia shortwave and RRTM longwave schemes), while parameterizations of cumulus, microphysics, surface layer, land surface, planetary boundary layer (PBL), and the temporal resolution of the entry of GFS were changed, generating 18 simulations between 10 January 2011 and 13 January 2011. The description of the parameterizations used in each of the 18 simulations is presented in Table 1. 
Table 1. Parameterizations used in each simulation of the WRF model in the respective tests.

\begin{tabular}{|c|c|c|c|c|c|}
\hline Simulations & $\begin{array}{c}\text { Cumulus } \\
\text { Parameterization }\end{array}$ & $\begin{array}{c}\text { Microphysics } \\
\text { Parameterization }\end{array}$ & $\begin{array}{c}\text { Surface Layer } \\
\text { Parameterization }\end{array}$ & PBL Parameterization & $\begin{array}{c}\text { Land Surface } \\
\text { Parameterization }\end{array}$ \\
\hline \multicolumn{6}{|c|}{ Test 1: Changing in cumulus parametrization (cu_physics) } \\
\hline R1 & 2 (Betts-Miller-Janjic) & 6 (wsm6) & 1 (MM5) & 99 (MRF) & 4 (Noah MP) \\
\hline $\mathrm{R} 2$ & 3 (Grell-Freitas) & 6 (wsm6) & 1 (MM5) & 99 (MRF) & 4 (Noah MP) \\
\hline R3 & 5 (Grell-3D) & 6 (wsm6) & 1 (MM5) & 99 (MRF) & 4 (Noah MP) \\
\hline $\mathrm{R} 4$ & 93 (Grell-Devenyg) & 6 (wsm6) & 1 (MM5) & 99 (MRF) & 4 (Noah MP) \\
\hline R5 & 1 (Kain-Fritsch) & 6 (wsm6) & 1 (MM5) & 99 (MRF) & 4 (Noah MP) \\
\hline \multicolumn{6}{|c|}{ Test 2: Changing in microphysics parameterization (mp_physics) } \\
\hline R6 & 2 (Betts-Miller-Janjic) & 1 (Kessler) & 1 (MM5) & 99 (MRF) & 4 (Noah MP) \\
\hline R7 & 2 (Betts-Miller-Janjic) & 7 (Goddard) & 1 (MM5) & 99 (MRF) & 4 (Noah MP) \\
\hline $\mathrm{R} 8$ & 2 (Betts-Miller-Janjic) & 5 (Ferrier-Aligo) & 1 (MM5) & 99 (MRF) & 4 (Noah MP) \\
\hline R9 & 93 (Grell-Devenyg) & 1 (Kessler) & 1 (MM5) & 99 (MRF) & 4 (Noah MP) \\
\hline R10 & 93 (Grell-Devenyg) & 7 (Goddard) & 1 (MM5) & 99 (MRF) & 4 (Noah MP) \\
\hline R11 & 93 (Grell-Devenyg) & 5 (Ferrier-Aligo) & 1 (MM5) & 99 (MRF) & 4 (Noah MP) \\
\hline \multicolumn{6}{|c|}{ Test 3: Changing in surface layer parameterization (sf_sfclay_physics) } \\
\hline R12 & 2 (Betts-Miller-Janjic) & 5 (Ferrier-Aligo) & 91 (MM5 old) & 99 (MRF) & 4 (Noah MP) \\
\hline R13 & 2 (Betts-Miller-Janjic) & 1 (Kessler) & 91 (MM5 old) & 99 (MRF) & 4 (Noah MP) \\
\hline \multicolumn{6}{|c|}{ Test 4: Changing in the PBL parameterization (bl_pbl_physics) } \\
\hline R14 & 2 (Betts-Miller-Janjic) & 5 (Ferrier-Aligo) & 91 (MM5 old) & $6(\mathrm{MYJ})$ & 4 (Noah MP) \\
\hline R15 & 2 (Betts-Miller-Janjic) & 5 (Ferrier-Aligo) & 1 (MM5) & $6(\mathrm{MYJ})$ & 4 (Noah MP) \\
\hline \multicolumn{6}{|c|}{ Test 5: Changing the input of GFS model to $6 \mathrm{~h}$} \\
\hline R16 & 2 (Betts-Miller-Janjic) & 5 (Ferrier-Aligo) & 1 (MM5) & 99 (MRF) & 4 (Noah MP) \\
\hline R17 & 2 (Betts-Miller-Janjic) & 5 (Ferrier-Aligo) & 91 (MM5 old) & 99 (MRF) & 4 (Noah MP) \\
\hline \multicolumn{6}{|c|}{ Test 6: Changing the land surface parameterization (sf_surface_physics) } \\
\hline R18 & 2 (Betts-Miller-Janjic) & 5 (Ferrier-Aligo) & 91 (MM5 old) & 99 (MRF) & 1 (Dudhia, 1996) \\
\hline
\end{tabular}


By analyzing the QPF in the WRF model with the grid of $1 \mathrm{~km}, 18$ simulations from the tests changing the parameterizations are described. The methodology used for the changes of parameterization in the tests is presented in the flowchart of Figure 6.

\begin{tabular}{|c|c|c|}
\hline $\begin{array}{c}\text { Test 1 } \\
\text { (Cumulus) }\end{array}$ & \\
\hline $\begin{array}{c}\text { Test 2 } \\
\text { (Microphysics) }\end{array}$ \\
\hline $\begin{array}{c}\text { Test 3 } \\
\text { (Surface layer) }\end{array}$ \\
\hline $\begin{array}{c}\text { Simulations that have stood out so far } \\
\text { and give rise to new tests: }\end{array}$ \\
\hline $\begin{array}{c}\text { Test 4 } \\
\text { (Planetary boundary layer) }\end{array}$ \\
\hline $\begin{array}{c}\text { Test 5 } \\
\text { (Input of GFS) }\end{array}$ \\
\hline $\begin{array}{c}\text { Test 6 } \\
\text { (Land surface) }\end{array}$
\end{tabular}

Figure 6. Flowchart of the methodology of the simulations, with emphasis on the parameterizations that best predicted the Quantitative Precipitation Forecasting (QPF) over Nova Friburgo.

Test 1 consisted of changing the parameterization of cumulus in the WRF namelist input, with 5 different options named as simulations R1 to R5, respectively: Betts-Miller-Janjic [36], Grell-Freitas [37], Grell 3D [38], Grell-Devenyi [39], and Kain-Fritsch [40]. The two cumulus parameterization options that better simulated the observed extreme rainfall were selected, proceeding to Test 2 of this meteorological experiment.

The second evaluation, named Test 2 (microphysics), consisted of alternating 3 different microphysics parameterizations in addition to the WSM6 [41], which was already tested previously. Then, 6 simulations were performed and referred to R6 to R11, with the following parameterizations tested: Kessler [42], Goddard [43], and Ferrier-Aligo [44]. Again, from the 11 simulations so far, the 2 simulations that better represented the observed rainfall on 11/01 were selected and proceeded to Test 3.

Test 3 (surface layer) consisted of evaluating the parameterization of surface layer physics by alternating the revised MM5 physics [45] that used the old MM5 [46], which was a standard configuration of the WRF model before its 3.6 version. As the revised MM5 parameterization proposes to improve flows in mountainous regions, the old MM5 parameterization was adopted to evaluate possible developments in the results.

From the 02 (two) simulations among the 13 (thirteen) mentioned before that best simulated the extreme rainfall in this period of study, the experiment proceeded to Test 4, which consisted of evaluating the parameterization of the planetary boundary layer (PBL). In this test, simulations were simulated by shifting the parameterization of PBL Medium Range Forecast (MRF) [47] for the Mellor-Yamada Nakanishi Niino PBL [48,49].

By this point, up to 15 simulations were generated. Next, Test 5 (GFS entry) consisted of evaluating a possible improvement of rainfall simulations by reducing the temporal input of the global model data in the WRF model, going from every $3 \mathrm{~h}$ to every $6 \mathrm{~h}$. The motivation for this test was the absence of moderate or heavy rainfall in the simulation from GFS on 11 January 2011, which could be a major factor in weakening the rain generated by WRF regional simulations. This way, by turning the WRF model more independent to perform the calculations needed for a longer time, it was possible to provide a better representation of extreme rainfall with less interference from the global model GFS. 
Thus, 02 (two) simulations were performed for this test, referred to R16 and R17, from the 02 (two) sets of parameterizations that best simulated the rainfall between R1 and R15.

Lastly, in Test 6 (land surface), the parameterization of the land surface was changed to Dudhia [50] in the simulation that best predicted the precipitation among the previous 18 simulations.

The initialization data of the WRF model was also investigated through the simulation of the event with the best set of parameters found between simulations R1 and R18. The initialization of the WRF model was compared with input data from the GFS model of the day 10/01 with the initialization with input data of the day 11/01.

\subsection{Floods: The SMAP Hydrological Model}

From the ensemble of QPF described previously, the SMAP hydrological model [51] was utilized and its description and calibration for the region of study are detailed in Cavalcanti et al. [30] for the prediction of flood waves.

QPF by 18 simulations in grid 3 of the WRF model, corresponding to the horizontal resolution of $1 \mathrm{~km}$, were extracted for each grid point to the corresponding 8 rain gauges used in the calibration of the hydrological model for the Rio Grande watershed by Cavalcanti et al. [30]. The location of the 8 (eight) rain gauges within the Rio Grande watershed and the grid of the WRF model with $1 \mathrm{~km}$ is shown in Figure 7. The rain gauge denominated Bom Jardim also has streamflow measurement and is called the hydrological station, and its streamflow data is used to verify the flood wave forecast.

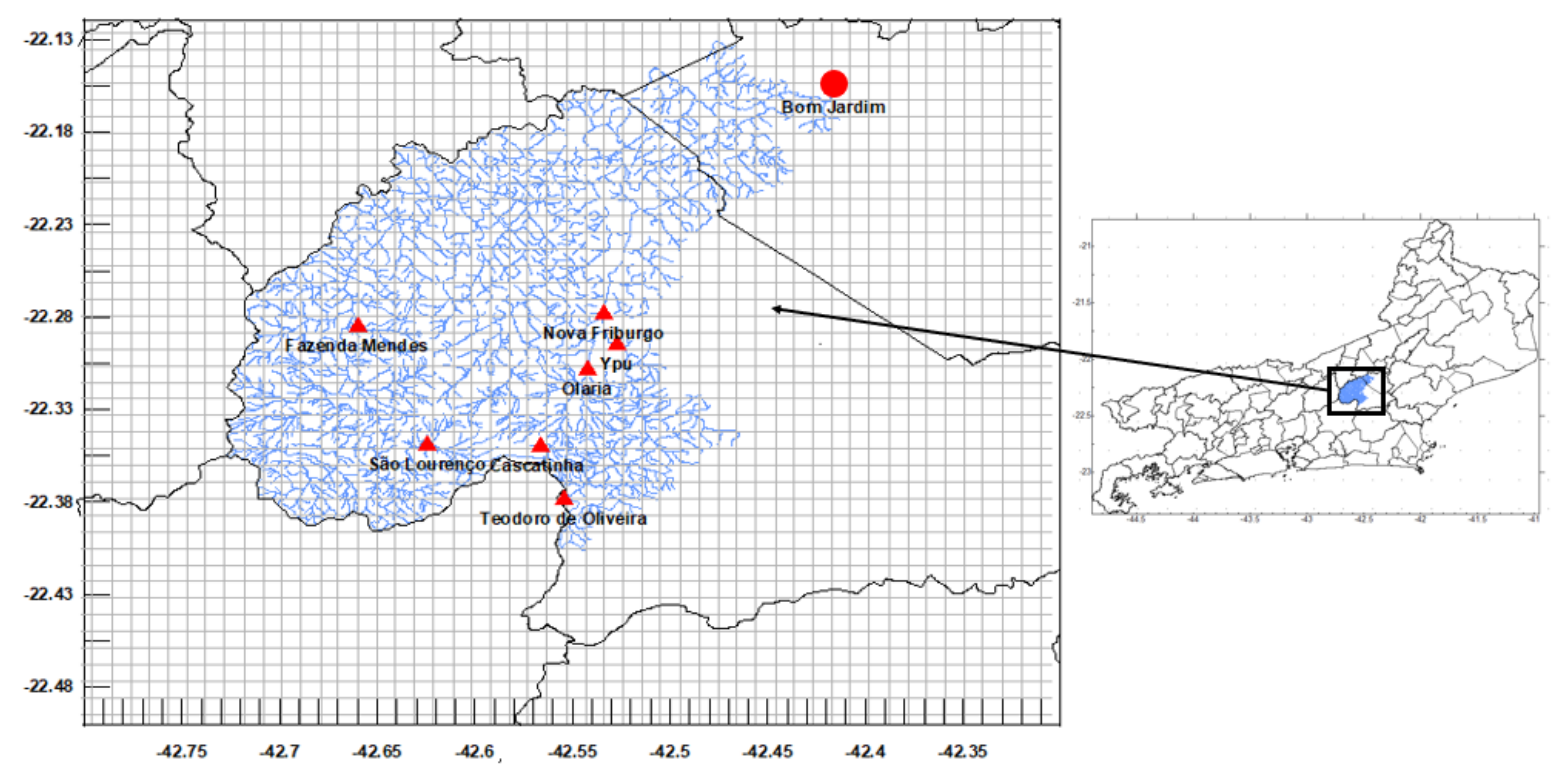

Figure 7. Location of 7 rain gauges (red triangle), hydrological station of Bom Jardim (red circle) within the Rio Grande watershed (blue shaded), and the grid of the WRF model with $1 \mathrm{~km}$ (gray checkered).

With the QPF for 8 grid points corresponding to rain gauges in each of the 18 simulations, those data were inserted into the SMAP model for predicting the streamflow of every simulation.

\section{Results}

\subsection{Meteorology}

For improving the visualization of the tests in the meteorological part of this research, it was chosen to illustrate the 3-h accumulated precipitation $(\mathrm{mm})$ for only the dates of 11 January 2011 at $21 \mathrm{Z}$ and 12 January 2011 at $00 \mathrm{Z}$ because they correspond to the highest QPF for this event.

It is important to highlight that the studied watershed is inserted in the northern part of the Nova Friburgo city, where QPF analysis and observations will be concentrated. 


\subsubsection{Test 1: Changing Cumulus Parametrization}

In the first test performed, Test 1, by changing the parametrization Cumulus in the namelist input of WRF, it was possible to observe a considerable difference in the spatial and temporal distribution of rainfall in the municipality of Nova Friburgo, where the Rio Grande watershed is, as shown in Figure 8a-e.

$11 / 01 / 2011-21 Z$

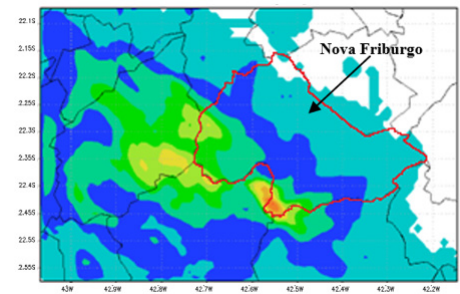

(a) R1: Betts-Miller-Janjic
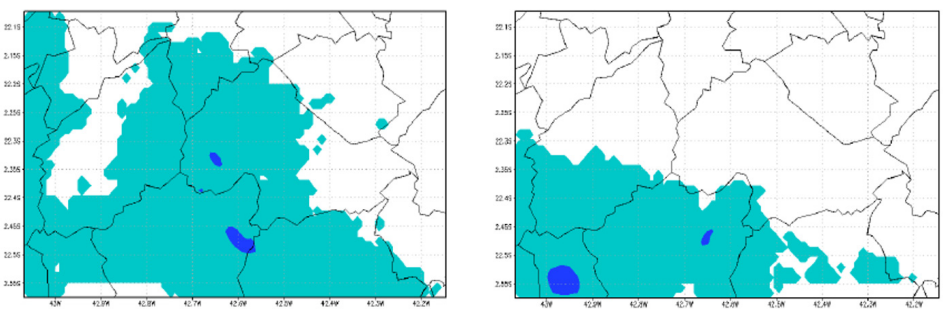

(b) R2: Grell-Freitas
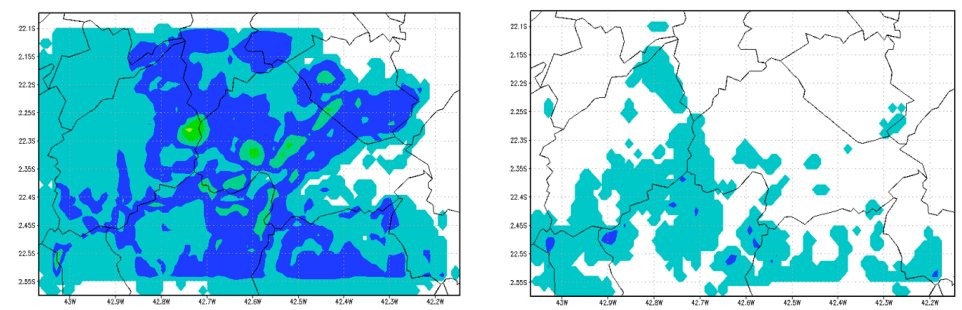

(c) R3: Grell-3D
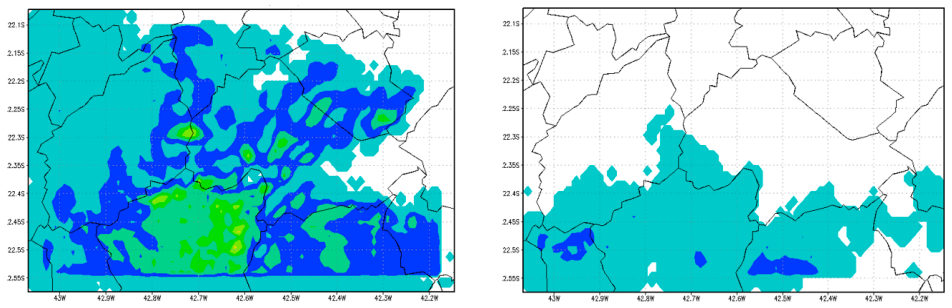

(d) R4: Grell-Devenyg
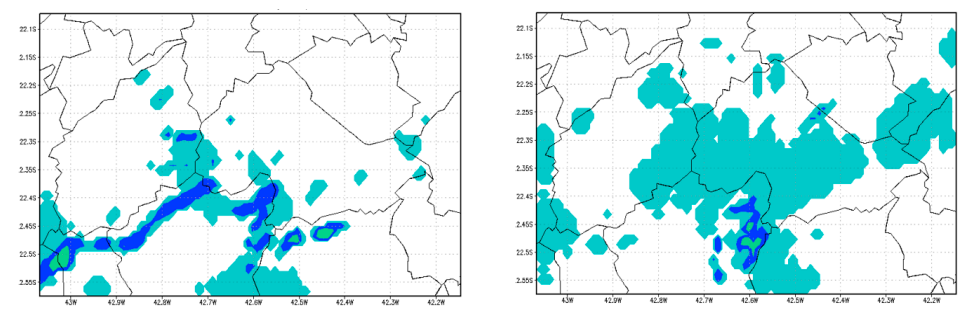

(e) R5: Kain-Fritsch

Figure 8. QPF accumulated in the $3 \mathrm{~h}(\mathrm{~mm})$ in Nova Friburgo city: Test 1-Changing in cumulus parametrization: (a) R1 Betts-Miller-Janjic, (b) R2 Grell-Freitas, (c) R3 Grell-3D, (d) R4 Grell-Devenyg, and (e) R5 Kain-Fritsch. 
The difference between the results by comparing the 5 simulations indicates R1 (Figure 8a) as the one that simulates the highest rainfall in Nova Friburgo city, even though it is still an underestimation of the precipitation observed during the hazard. The other simulations did not predict any significant precipitation for the event.

R1 (Figure 8a) with Betts-Miller-Janjic scheme had accumulated precipitation of around $50 \mathrm{~mm}$ per $3 \mathrm{~h}$ in the municipality of Teresópolis, neighboring Nova Friburgo and located at west of the watershed. However, it did not reach a significant rainfall measurement over the region of study, with QPF with maximum values of $20 \mathrm{~mm} / 3 \mathrm{~h}$ in the southwest of the watershed.

R2 (Figure 8b) with Grell-Freitas scheme and R5 (Figure 8e) with Kain-Fritsch scheme forecast light or null rainfall during the period. R3 (Figure 8c) with Grell-3D scheme and R4 (Figure 8d) with Grell-Devenyg forecast light to moderate rainfall concentrated in neighboring cities located southwest of the basin at $21 \mathrm{Z}$ and both did not forecast rainfall at $00 \mathrm{Z}$ over the studied watershed.

Although the results forecasted unsatisfactory in comparison to the observed rainfall, the best forecasts identified were simulations R1 and R4, which proceeded to Test 2.

\subsubsection{Test 2: Changing Microphysics Parametrization}

In the second test, three different microphysics parameterizations were evaluated in addition to the WSM6 previously tested, and results are illustrated in Figure 9a-f.

The results of this test emphasize the importance of the microphysics parameterization in representing the precipitation of the event. Changing this parametrization provided a significant difference in forecasting this disaster.

R8 (Figure 9c) stood out from the other simulations, with QPF greater than $60 \mathrm{~mm} / 3 \mathrm{~h}$ in $00 \mathrm{Z}$ in the north and northeast of Nova Friburgo city and the watershed, and its surrounding cities have even higher QPF.

R6 (Figure 9a) also stood out from other simulations, slightly increasing the QPF in Nova Friburgo on 12/01 at 00Z, as well as increasing the intensity of convective cells in the previous time in the cities located in southwest and west of the Nova Friburgo city.

R7 (Figure 9b) and R10 (Figure 9e) that used Goddard scheme forecast light rain throughout the mountainous region throughout the period, and simulations R9 (Figure 9d) with Kessler scheme and R11 (Figure 9f) with Ferrier-Aligo scheme spatially forecast a light distributed QPF, with small cells of moderate rainfall, throughout the watershed, with this pattern most observed in $21 \mathrm{Z}$.

Thus, R8 and R6 proceeded to Test 3.

\subsubsection{Test 3: Changing Surface Layer Parametrization}

The third test performed changed the physics schemes of the surface layer. In this test, two different parameterizations were compared: Revised MM5, previously tested, and the old MM5 scheme. Results are presented in Figure 10.

This test revealed that the configuration of the surface layer interferes with the intensity and spatial distribution of the QPF. In both simulations, precipitation increased in intensity over Nova Friburgo city, turning out more to be more significant in R12 (Figure 10a).

In 00Z, the spatial distribution of QPF in the R12 simulation concentrated heavy rainfall in the east and northeast part of the watershed, while in the southeastern part of the basin, heavy to moderate rain was observed only in the QPF of the $21 \mathrm{Z}$ time. The analysis shows that, despite the underestimated $\mathrm{QPF}$, the spatial pattern is consistent with the distribution of observed rainfall.

R13 (Figure $10 \mathrm{~b}$ ) did not reach QPF above $20 \mathrm{~mm} / 3 \mathrm{~h}$, registering moderate QPF only in cities located southwest of the watershed.

So far, R8 (Figure 9c) and R12 (Figure 10a) are considered the best simulations for QPF of the event studied. Hence, we proceeded to the next test. 
11/01/2011-21Z

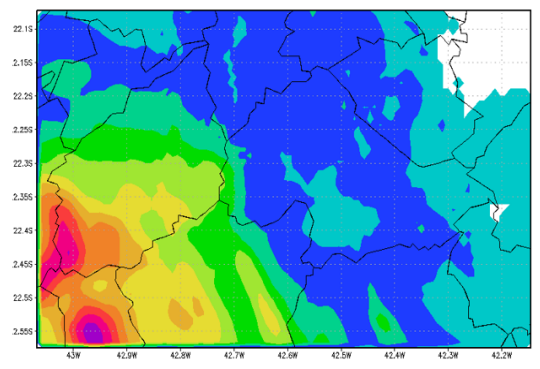

(a) R6: Kessler
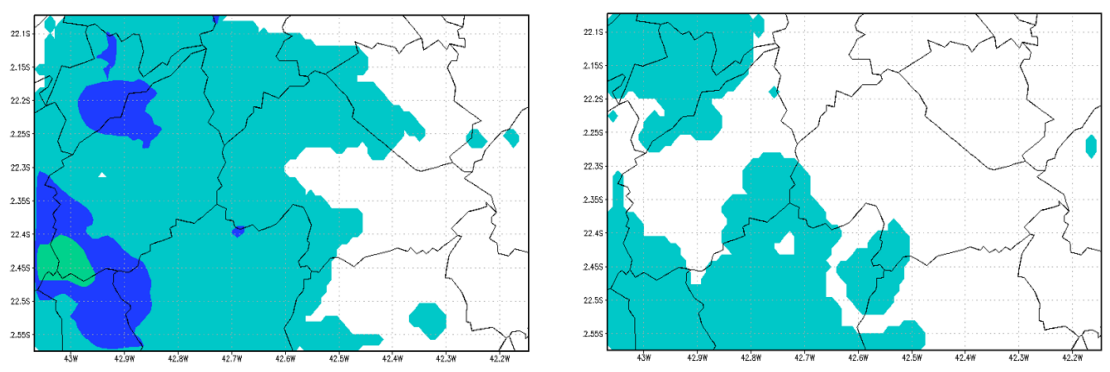

(b) R7: Goddard
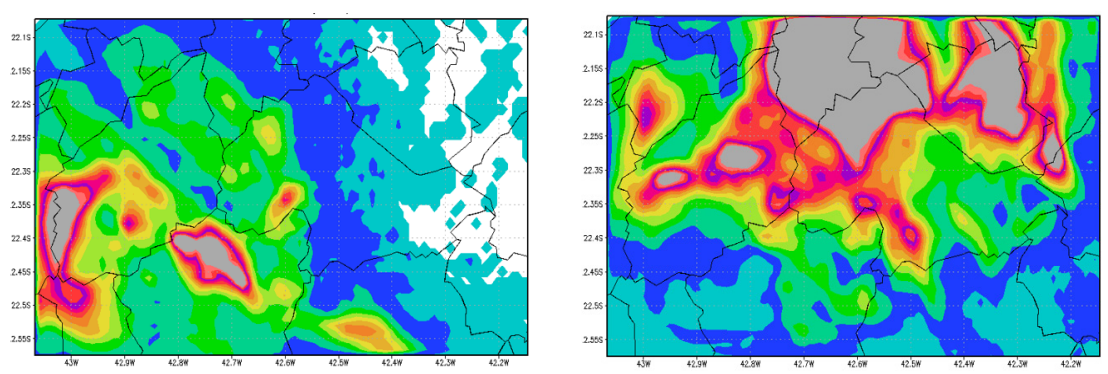

(c) R8: Ferrier-Aligo
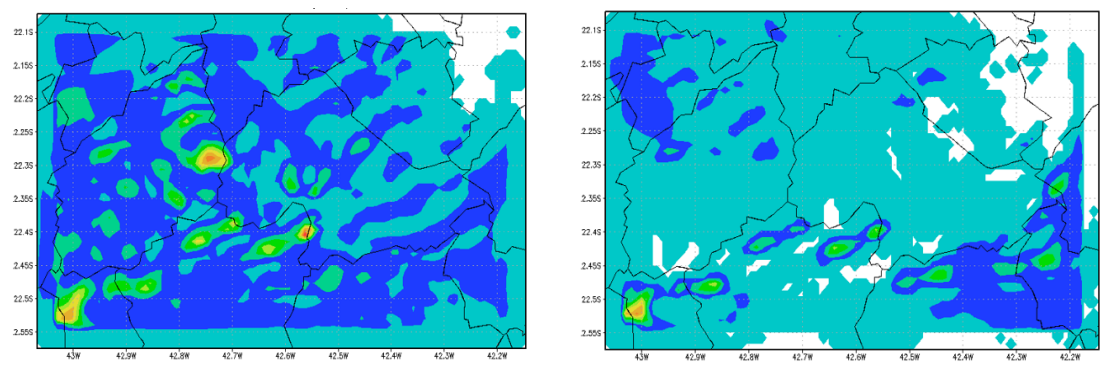

(d) R9: Kessler
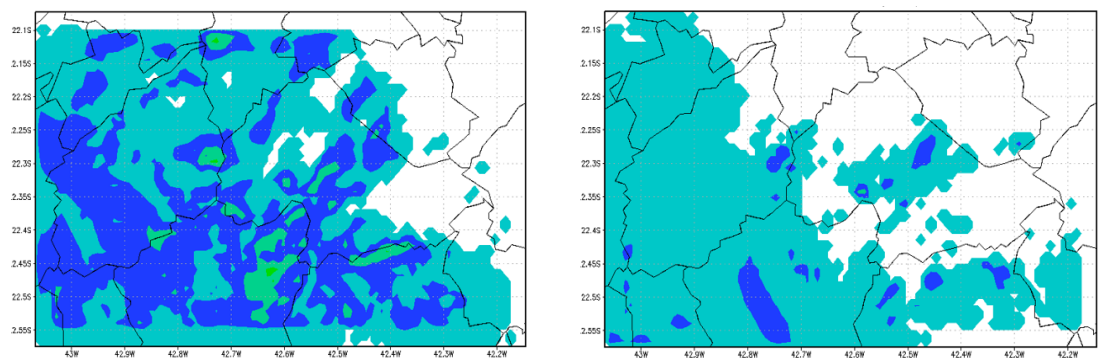

(e) R10: Goddard

Figure 9. Cont. 

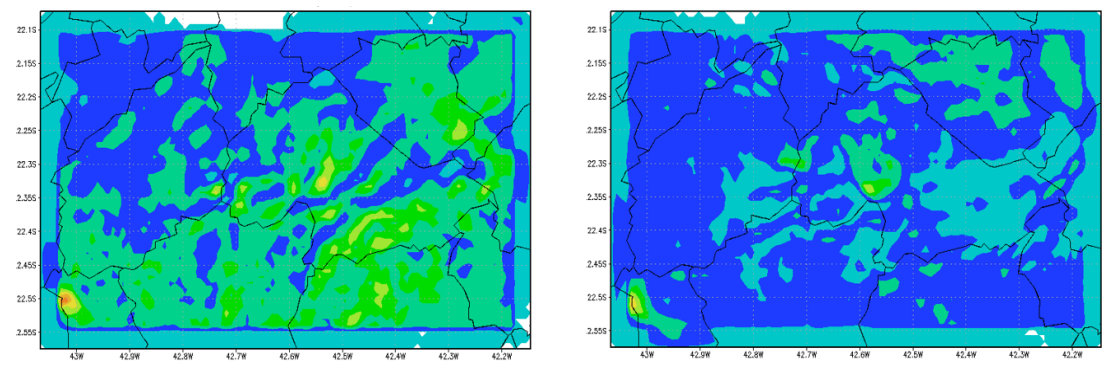

(f) R11: Ferrier-Aligo

Figure 9. QPF accumulated in the $3 \mathrm{~h}(\mathrm{~mm})$ in Nova Friburgo city: Test 2-Changing in microphysics parametrization: (a) R6 Kessler, (b) R7 Goddard, (c) R8 Ferrier-Aligo, (d) R9 Kessler, (e) R10 Goddard, and (f) R11 Ferrier-Aligo.

$11 / 01 / 2011-21 Z$

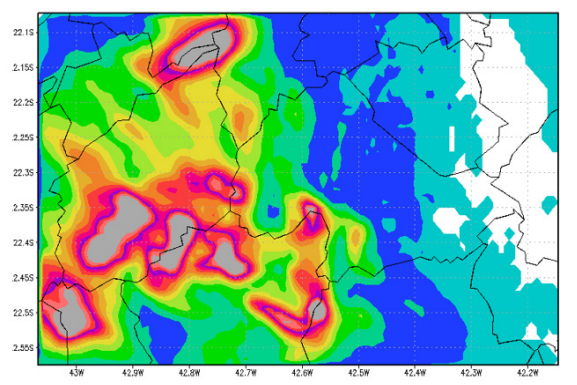

(a) R12: old MM5 scheme

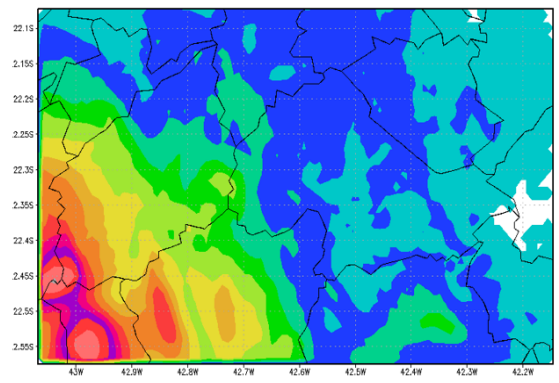

$12 / 01 / 2011-00 Z$
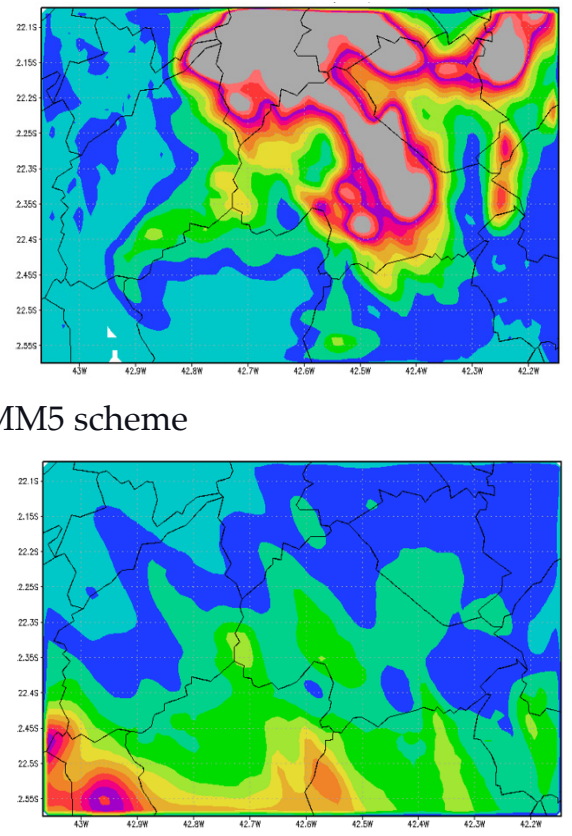

(b) R13: old MM5 scheme

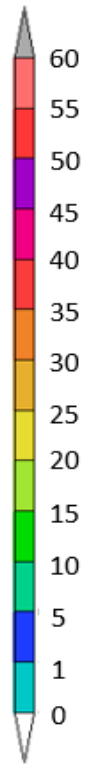

\section{0}

55

50

45

35

30

25

20

15

10

5

0

Figure 10. QPF accumulated in the $3 \mathrm{~h}(\mathrm{~mm})$ in Nova Friburgo city: Test 3-Changing in surface layer parametrization: (a) R12 old MM5 scheme, and (b) R13 old MM5 scheme.

\subsubsection{Test 4: Changing Planetary Boundary Layer Parametrization}

In the fourth test performed, the change consisted of observing the role of the planetary boundary layer (PBL) parameterization. The MRF parameterization was compared to the Mellor-Yamada Nakanishi Niino (MYNN), and the results are presented in Figure 11.

By analyzing the outcome, it is observable that altering this parameterization decreased significantly the intensity of the precipitation of the original simulations (R8 and R12). Light to moderate QPF was forecasted in both simulations of this test, with light QPF spatially distributed over almost the entire watershed.

Thus, those two sets of parameterizations are still considered the best forecasting for the event so far. R8 and R12 then proceeded to the next step. 
$11 / 01 / 2011-21 Z$

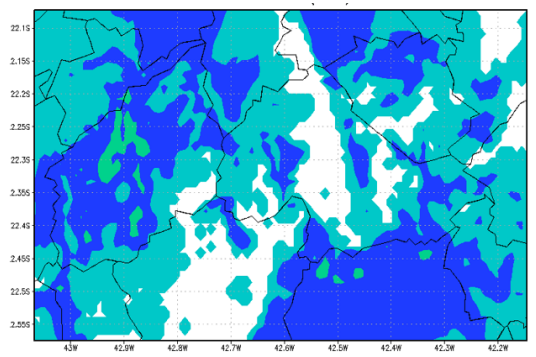

(a) R14: MYNN

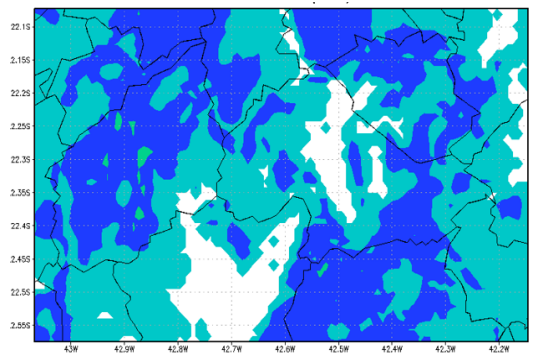

$12 / 01 / 2011-00 Z$
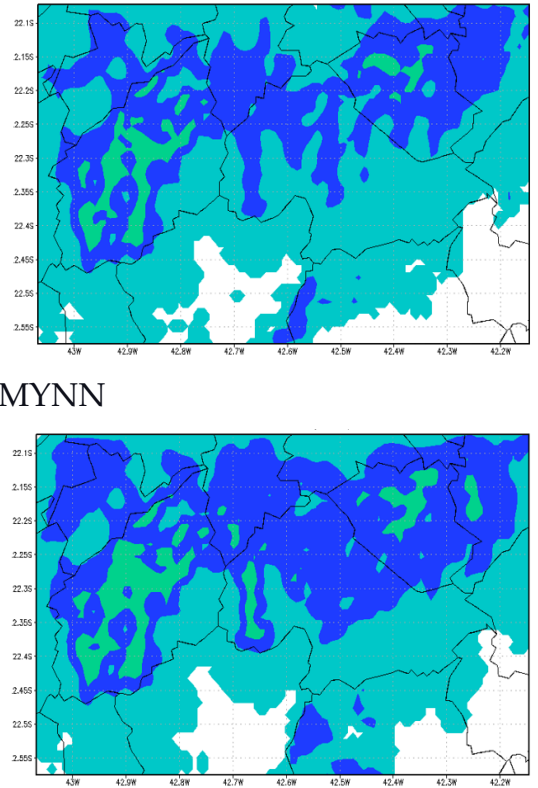

(b) R15: MYNN

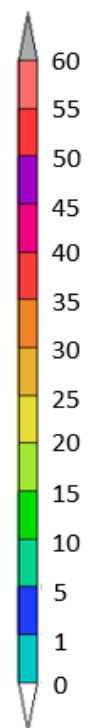

60

55

50

35

30

25

20

15

5

1
0

Figure 11. QPF accumulated in the $3 \mathrm{~h}(\mathrm{~mm})$ in Nova Friburgo city: Test 4-Changing in Planetary Boundary Layer parametrization: (a) R14 MYNN, and (b) R15 MYNN.

\subsubsection{Test 5: Changing Input of GFS Model}

Test 5 consisted of determining the influence of the boundary data from the global model GFS on predicting the outcome in the regional model. The temporal input of the global model was changed to $6 \mathrm{~h}$. Figure 12 shows the results.

$11 / 01 / 2011-21 Z$

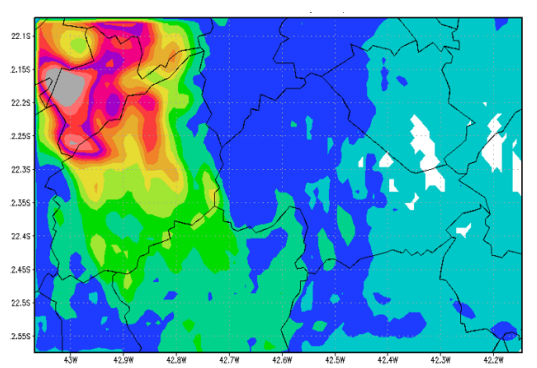

(a) R16: R8 with temporal input of the global model changed to $6 \mathrm{~h}$

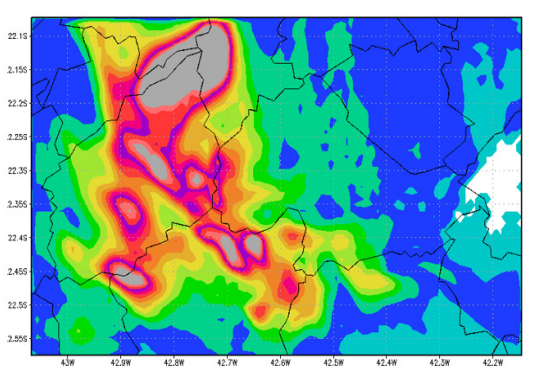

$12 / 01 / 2011-00 Z$
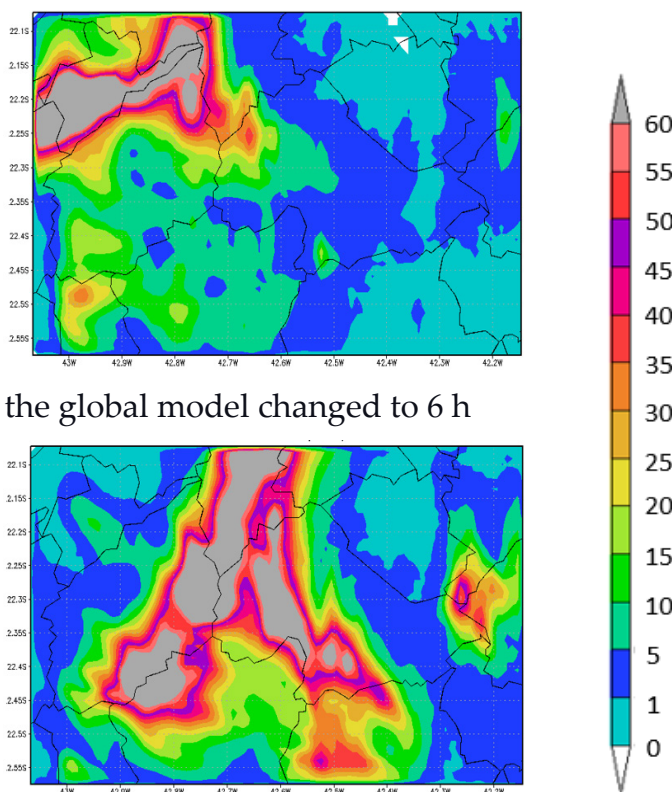

(b) R17: R12 with temporal input of the global model changed to $6 \mathrm{~h}$

Figure 12. QPF accumulated in the $3 \mathrm{~h}(\mathrm{~mm})$ in Nova Friburgo city: Test 5-Changing the input of GFS model: (a) R16: R8 with temporal input of the global model changed to $6 \mathrm{~h}$, (b) R17: R12 with temporal input of the global model changed to $6 \mathrm{~h}$. 
This test demonstrated that by altering the GFS input of boundary data to every $6 \mathrm{~h}$ instead of $3 \mathrm{~h}$, the convective cell over Nova Friburgo was weakened in comparison to the R8 and R12 simulations (Figures $9 \mathrm{c}$ and 10a).

Comparing R12 with R17, in $21 Z$ the heavy QPF is observed to the west of the watershed, with very similar spatial distribution in both simulations. In 00Z, the heavy QPF is observed in the central, northwest, and west of the watershed in R17 and in the north, northeast, and east on R12. Analyzing the spatial distribution of the QPF, the R12 is more similar to the spatial distribution of rainfall observed by the rain gauges on 11 January than the R17.

Comparing R8 with R16, it is possible to observe that in 00Z the QPF was lower in R16 than in $\mathrm{R} 8$, forecasting greater accumulation of rainfall only in the neighboring city located northwest of the studied watershed, without the forecast of heavy QPF for the region to the north of watershed as predicted in R8.

\subsubsection{Test 6: Changing Land Surface Parametrization}

Test 6 consisted of changing the parameterization of the land surface in R12 by replacing the Noah MP parameterization for Dudhia [50]. As shown in Figure 13, it is possible to note that the precipitation weakened over Nova Friburgo and its surroundings, with a more intense convective cell appearing only in the southern portion of the municipality.

$11 / 01 / 2011-21 Z$

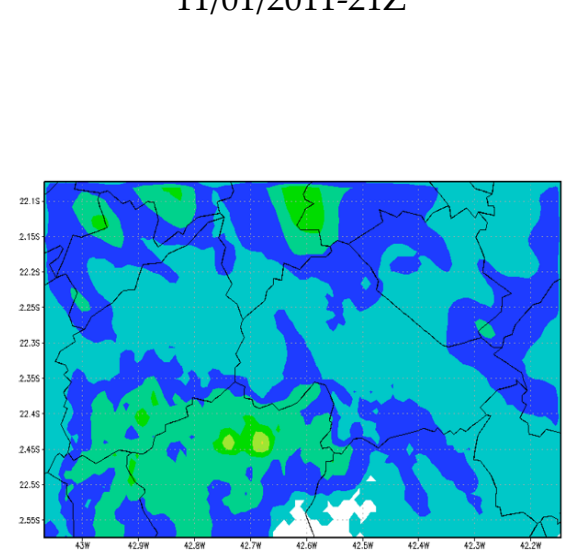

$12 / 01 / 2011-00 Z$

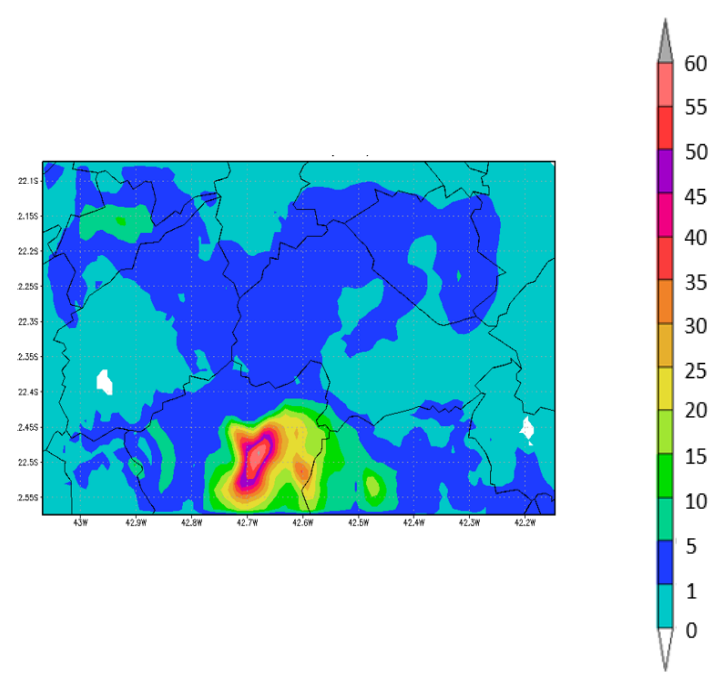

Figure 13. QPF accumulated in the $3 \mathrm{~h}(\mathrm{~mm})$ in Nova Friburgo city: R18: Changing the land surface.

\subsubsection{Changing Lead Time}

As a complement to the study, the model's lead time was investigated using the same parametric schemes configurations as the R12 simulation and with the change in the WRF model's initialization date and GFS input data for 11 January. Figure 14 shows the QPF for the study region.

Comparing the results of Figure 14 with simulation R12 (Figure 10a), it is possible to notice that at $21 Z$ the QPF increased the intensity of rainfall over the central and northern part of the watershed when R12 predicted only heavy rainfall in neighboring cities located at west and southwest of the watershed. However, in 00Z, QPF decreased dramatically within the watershed compared to R12, which predicted heavy rain across the central, northern, and northeastern regions of the watershed. Although the QPF was higher at 21Z, the total accumulated QPF decreased compared to R12, showing that the model had more ability to forecast the QPF when it was started $24 \mathrm{~h}$ before the start date of the studied event. 

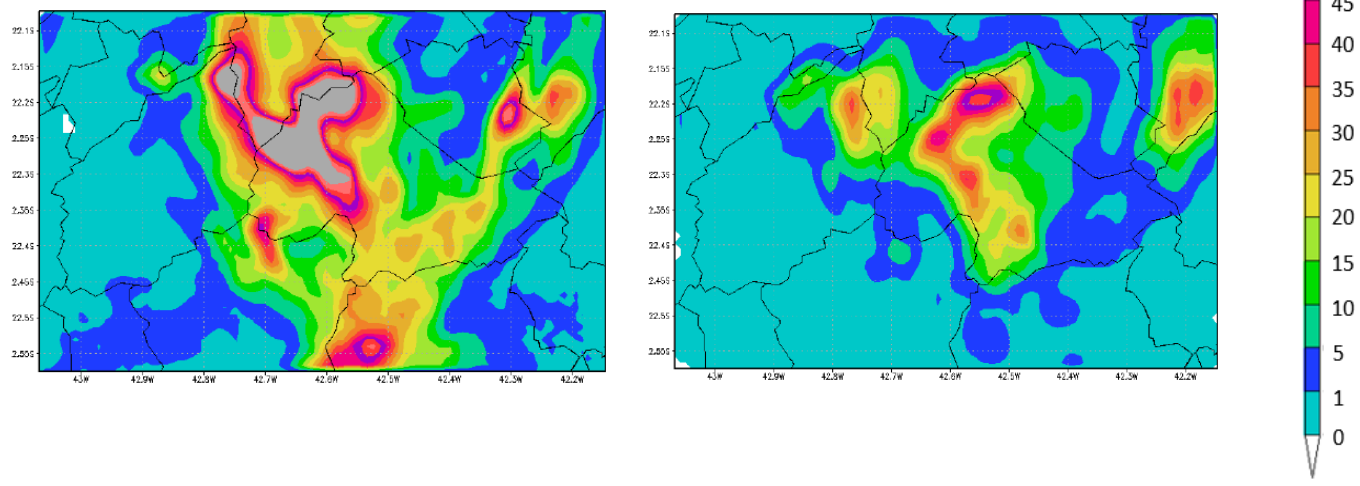

Figure 14. QPF accumulated in the $3 \mathrm{~h}(\mathrm{~mm})$ in Nova Friburgo city: Changing lead time, WRF model initialized on $01 / 11$.

\subsection{Hydrology}

Subsequently, the QPF data were extracted in $24 \mathrm{~h}$ in each 8 rain gauges of the watershed (described in Section 2.4), and it generated the expected streamflow for each simulation of the QPF, achieving an ensemble for streamflow through the coupling of WRF and SMAP models.

The QPF for 10 January 2011 and 11 January 2011 was extracted and did average precipitation forecasting in the watershed for each simulation then was used in the SMAP model for forecasting the streamflow on the day of the event.

It is important to emphasize that the average QPF for all 18 simulations in each rain gauge was highly underestimated by the WRF, revealing its difficulty in predicting extreme events in these regions of the watershed.

By analyzing the average precipitation forecasting for every simulation throughout the watershed in comparison to the observed average rainfall (Figure 15), it is reasoned that all simulations are underestimated by more than $57 \%$ the average rainfall for this event in the watershed, with the simulations R8, R12, and R17 as the ones that most closely approximated the observed average precipitation.

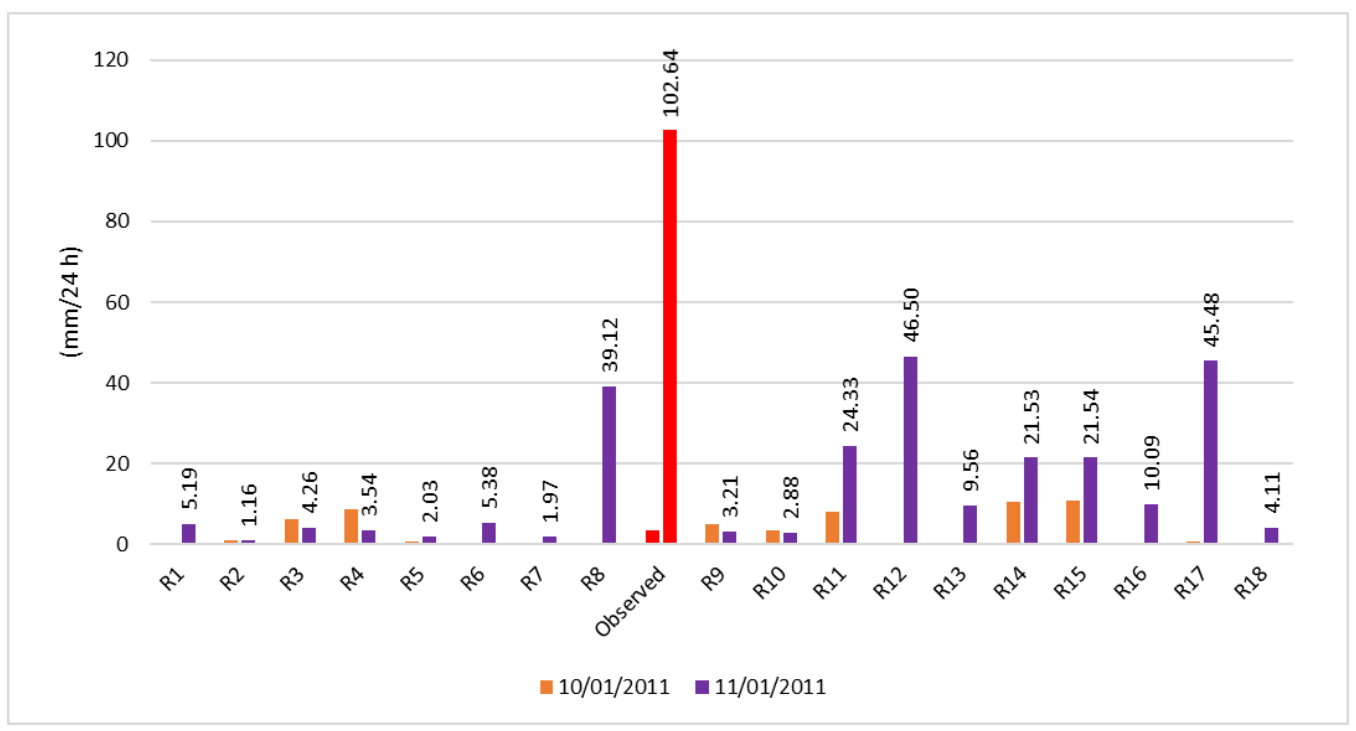

Figure 15. Average QPF in the 18 simulations and observed average rainfall on 10 January 2011 and 11 January 2011. 
Forecasting Streamflow by the SMAP-WRF Ensemble

Through the QPF by the 18 simulations in WRF model, and with the calibration of the Rio Grande watershed in the SMAP model [30], it was possible to construct the streamflow forecast plume for the hydrological station of Bom Jardim, producing an operational streamflow forecast.

For each simulation, the observed precipitation accumulated on 09/01 was maintained, while on 10 January 2011 and 11 January 2011 the QPF from the WRF was used as input in the SMAP model. This plume is shown in Figure 16.

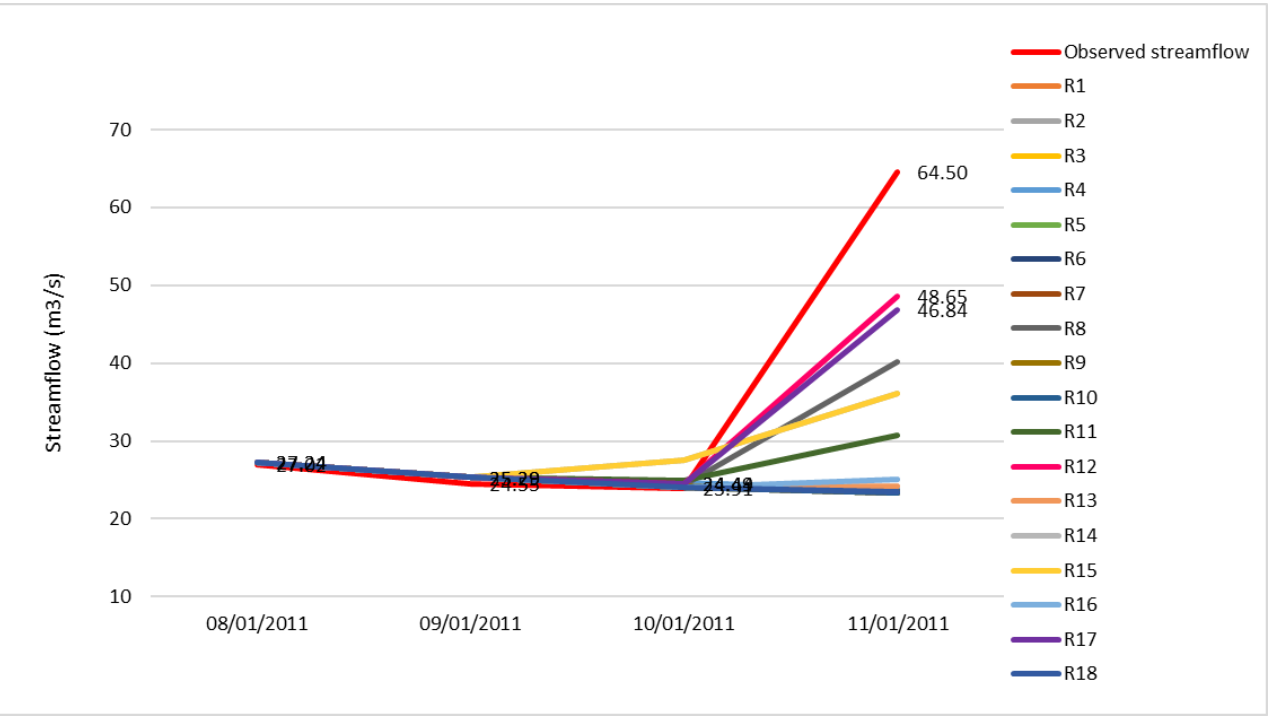

Figure 16. Observed data (red line) and set of streamflow forecasts through the coupling of the WRF-Soil Moisture Accounting Procedure (SMAP) models at the Bom Jardim hydrological station.

By comparing these results with the observed streamflow, it is possible to note that even with the forecast that came closest to the observed streamflow, it still underestimated the observed data by $24.6 \%$. R12, R17, and R8 stood out as the simulations that came closest to the streamflow registered at the hydrological station.

As the rain gauges and hydrological station of the watershed were destroyed by the flash floods, the National Water Agency (Agência Nacional de Águas-ANA) reconstructed the data, and its comparison with the predictions of the ensemble WRF-SMAP are illustrated in Figures 17 and 18.

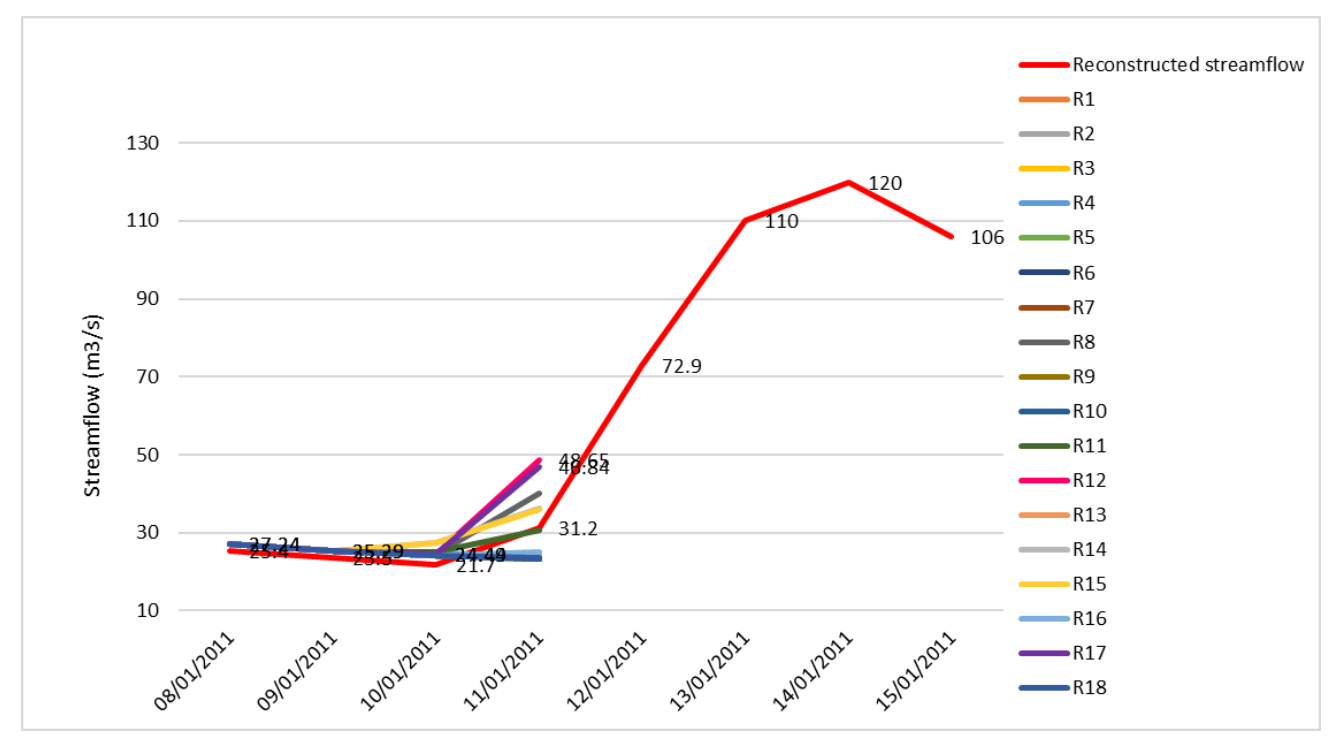

Figure 17. Reconstructed data (red line) and set of streamflow forecasts through the coupling of the WRF-SMAP models at the Bom Jardim hydrological station between 8 January and 15 January 2011. 


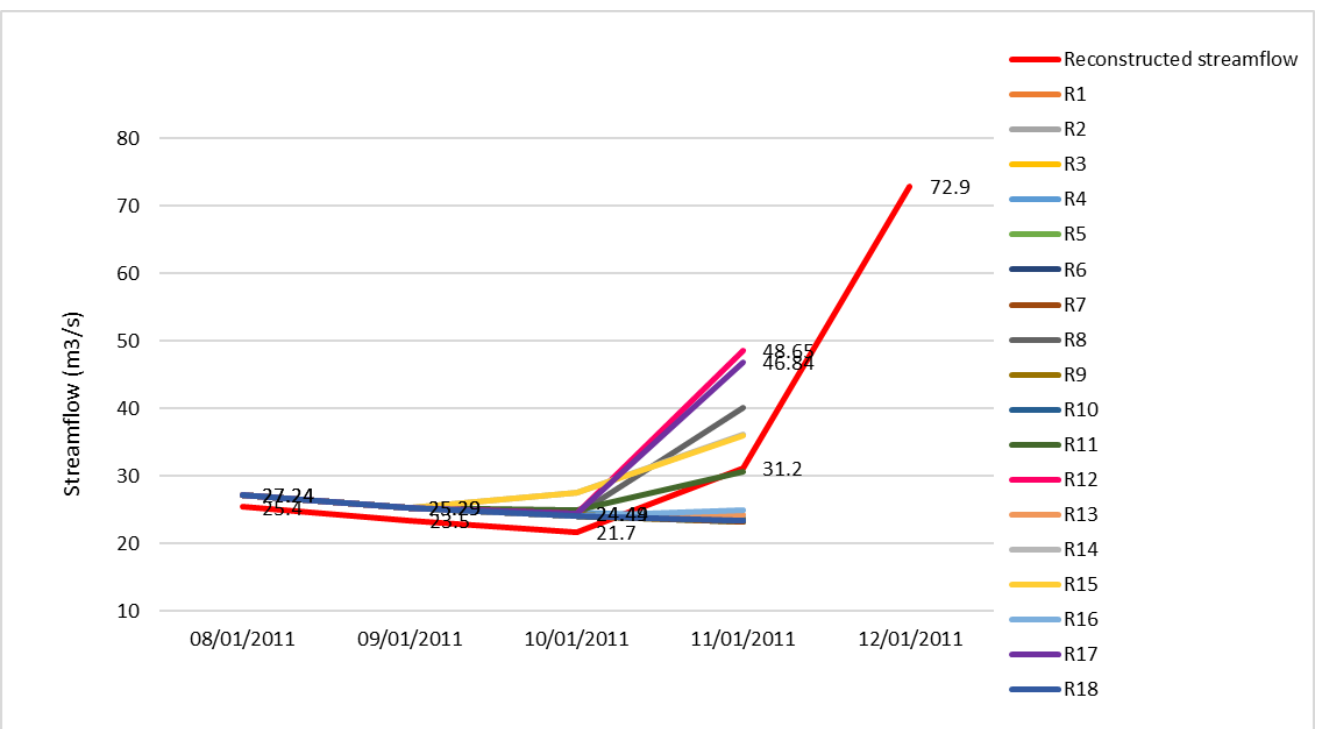

Figure 18. Reconstructed data (red line) and set of streamflow forecasts through the coupling of the WRF-SMAP models at the Bom Jardim hydrological station between 8 January and 12 January 2011.

WRF-SMAP streamflow forecasts were closest to the reconstructed streamflow more than to the observed streamflow. It is valid to highlight that the reconstructed data displaced the peak of wave temporally, on 14 January 2011. This is a serious mistake considering that after the event on 11 January 2011, the watershed was destroyed and tailings and mud in the rivers obstructed the flow of water.

\section{Discussion}

The results of the meteorological part show that, despite the changes made with several sets of parameterization, the QPF was underestimated in all simulations, in agreement with the studies by Kala et al. [27] in Australia and Attada et al. [29] in the Peninsula Arabica.

Changes in cumulus parametrization, the Betts-Miller-Janjic parameterization presents a few relevant distinctions to be considered, such as the inclusion of a cloud efficiency parameter and the adjustment of convection of shallow clouds, improvements made by changing the integer of some parameters after evaluations of operational simulations at the NCEP [52]. These improvements seem to assist in improving the formation of storms that occurred in the event studied.

Evaluating changes in microphysical parameterization, the Ferrier-Aligo scheme, used operationally in NCEP models, is characterized by a simple and efficient scheme with mixed-phase cloud diagnostic processes used at high resolutions $(<5 \mathrm{~km})$ [44]. Using the $1 \mathrm{~km}$ spatial resolution in this study, this parameterization proved to be the best parametric scheme to improve the QPF, highlighting the importance of considering the mixed-phase in the growth of the cloud for the simulated event.

Considering that the event was configured as heavy rainfall that affected much of the mountainous region of Rio de Janeiro state, the alteration of the parameterization of the superficial layer sought to improve the flows of this layer when the revised MM5 scheme was used, which, as proposed, seeks to improve the soil resolution, including in mountainous areas, removing edges and using updated stability functions [45]. When the Revised MM5 scheme was changed by the old MM5 scheme, it was observed that the Revised MM5 scheme was not the best option for the unique topography of the studied region.

There was also no significant improvement in the QPF when the input of the global GFS model was changed in the regional WRF model. Even though the global GFS model did not forecast the event's rainfall, the regional model was able to forecast the event with both the 3-h and 6-h input, which demonstrates the importance of the downscaling.

The analysis of the change in Land Surface Parametrization from Noah MP in 2011 to Dudhia in 1996 showed that this parameterization directly influences the generation of convective flows in the 
atmosphere, and a more recent parameterization, as Noah MP, had a better performance to forecast rainfall occurred in the studied event.

Used as an input for the hydrological model, the average rainfall forecast in the watershed highlights the problem of numerical weather prediction for forecasting extreme events, with results of the average of the QPF underestimating in more than $57 \%$ the average of the observed rainfall in the region. These results bring light to the lack of skill of the WRF model to forecasting the precipitation in the watershed located in the mountainous region of the state of Rio de Janeiro for all 18 sets of parameterizations tested in this research.

The analysis of the changes in the model's lead time showed that the initialization of the WRF model with the input data from the GFS on 1/10 simulated the precipitation that occurred better than when the model was initialized on the day of the event, on 1/11. Padilha [53] investigated the same natural hazard in the mountainous region of Rio de Janeiro with the WRF model and input data with GFS model, using the combination of Kain-Fritsch cumulus parameterization with two parametric microphysical schemes: WRF Single-moment 3-class and Goddard, and concluded that, in addition to both simulations underestimating the rainfall of the event, the initialization with GFS data from 9 January proved to be unable to forecast the extreme event, with precipitation forecast only on the night of the 12 January $24 \mathrm{~h}$ after the real occurrence of the event. The comparison of these simulations brings up the discussion about the spin-up of the numerical weather prediction about the QPF, which, in this study, obtained the best performance in the simulate started $48 \mathrm{~h}$ before the extreme event.

In the hydrological forecast, errors associated with the meteorological model were transferred to the hydrological model as already demonstrated in studies like Adams and Dymond [15]. The results showed that the peak of the flood wave was underestimated by more than $24 \%$ by the forecast, and even so, they indicate the arrival of the flood wave at the location, which makes the results promising to be used in alert systems in the region.

In Brazil, when a data series is lost due to a failure in hydrological sensors or for other reasons, the government agency called ANA is responsible for consisting of the data and completing the data series. In the case of the natural hazards that occurred, the reconstruction of data showed its inefficiency to study the event, since there was a 2-day displacement of the occurrence of the peak of the flash flood and even constructed data as if the disaster had characteristics of gradual flooding, which was not true. In this research, it was possible to highlight that it is necessary to be very careful when using data from this reconstruction technique, as it is not always able to accurately capture the characteristics of the event that occurred.

In recent years, with advances in technology, studies in numerical weather prediction have focused on improvements in numerical equations and coding, and not so much on experimentation in the clouds, taking as true parametric constants measured in clouds of a given atmospheric reality [54]. These constants were measured in the 1970s and 1980s, such as the experiments carried out at the Global Atlantic Tropical Experience-GATE [55], which served as a subsidy for the definition of the climatological profiles used in the parameterization Betts-Miller-Janjic and experiments of Dye et al. [56] to measure the freezing temperature in the Ferrier-Aligo parametric scheme, and they no longer represent the atmosphere of today's reality, not only in the face of increased pollution but also climate change. Moreover, it is known that each location on the planet has its specific and representative physics/dynamics only in that area and that there are also differences found in the clouds that are formed over the continent and the oceans [57].

Thus, to improve the QPF in numerical weather prediction, future research efforts aimed at in situ experimentation in the clouds are suggested as numerical modeling is limited not only by observational data but also depends on these data for its validation and development of more improved and regionalized parameterizations. 


\section{Conclusions}

Flash floods can cause major natural hazards, especially where the affected regions comprise a high risk of exposure to the phenomenon, as in the case of the event of January 2011 in the mountainous region of Rio de Janeiro.

As a central tool for the prevention and protection of populations at risk, alert systems that use hydrometeorological forecasting is the first step in decision-making actions to develop alerts system in vulnerable communities. Nonetheless, the physics complication in simulating floods is not compatible with the real-time restriction that meteorologists face predicting those phenomena. Numerical modeling requires testing and accuracy for regions and areas that need protection.

In this context, this research simulated the natural hazards that occurred in January 2011 in the mountainous region of the state of Rio de Janeiro. Through the execution of 18 simulations of precipitation forecasting in the numerical weather prediction WRF, which coupled with the SMAP hydrological model previously calibrated, proposed to predict the streamflow in the Rio Grande watershed, one of the most affected regions during the event.

Results revealed the lack of skill of the meteorological model in predicting extreme precipitation events over the mountainous region, which contributed strongly to the errors propagated to the hydrological model. This issue is associated with the necessity in adaptations of numerical weather prediction, especially in their parametric schemes, to improve their representations of empirical constants to adequate the atmospheric, topographic, and geographic reality of the region where the model is applied.

Thus, advances in hydrological models need to be aligned with advances and adaptation of numerical weather prediction to Brazilian specificities, considering that every QPF of the WRF may transfer significant errors to the streamflow prediction.

Notably, the plume of the forecast streamflow of the set indicates that there is a forecast of increased streamflow in the subsequent hours. Although those values are not as high as the observed ones, they represent an important indication that a natural hazard could happen in the region if this modeling system were operational by the time of the event.

Author Contributions: Conceptualization, P.d.C.L.B. and M.C.; investigation, P.d.C.L.B.; methodology, P.d.C.L.B. and M.C.; resources, P.d.C.L.B.; supervision, M.C.; visualization, P.d.C.L.B.; writing-original draft, P.d.C.L.B.; writing-review and editing, P.d.C.L.B. and M.C. All authors have read and agreed to the published version of the manuscript.

Funding: This research received no external funding.

Conflicts of Interest: The authors declare no conflict of interest. The funders had no role in the design of the study; in the collection, analyses, or interpretation of data; in the writing of the manuscript; or in the decision to publish the results.

\section{References}

1. World Bank, 2012: Loss and Damage Assessment: Floods and Landslides in the "Serrana" Region of Rio de Janeiro-January 2011. Available online: http://mi.gov.br/pt/c/document_library/get_file?uuid=74dde46c544a-4bc4-a6e1-852d4c09be06\&groupId=10157 (accessed on 14 March 2018).

2. Moura, C.R.W.; Escobar, G.C.J.; Andrade, K.M. Padrões de circulação em superfície e altitude associados a eventos de chuva intensa na região metropolitana do Rio de Janeiro. Rev. Bras. Meteorol. 2013, 28, 267-280. [CrossRef]

3. Viterbo, F.; Mahoney, K.; Read, L.; Salas, F.; Bates, B.; Elliott, J.; Cosgrove, B.; Dugger, A.; Gochis, D.; Cifelli, R. A Multiscale, Hydrometeorological Forecast Evaluation of National Water Model Forecasts of the May 2018 Ellicott City, Maryland, Flood. J. Hydrometeor. 2020, 21, 475-499. [CrossRef]

4. NCAR, 2010: Flash Flood Early Warning System Reference Guide. Available online: https://www.meted. ucar.edu/communities/hazwarnsys/ffewsrg/FF_EWS.pdf (accessed on 3 November 2015).

5. Sun, D.; Zhang, D.; Cheng, X. Framework of National Non-Structural Measures for Flash Flood Disaster Prevention in China. Water 2012, 4, 272-282. [CrossRef] 
6. Barcellos, P.C.L.; Da Costa, M.S.; Cataldi, M.; Soares, C.A.P. Management of non-structural measures in the prevention of flash floods: A case study in the city of Duque de Caxias, state of Rio de Janeiro, Brazil. Nat. Hazards 2017, 89, 313-330. [CrossRef]

7. Faisal, I.M.; Kabir, M.R.; Nishat, A. Non-structural flood mitigation measures for Dhaka City. Urban Water 1999, 1, 145-153. [CrossRef]

8. Calmant, S.; Lee, H.; Souza, A.E.; Shum, C.K.; Seyler, F.; Huang, Z.; Ries, J. JASON-2 IGDRs for Flood Alert in the Amazon Basin. In Proceedings of the Ocean Surface Topography Science Team Meeting, Seattle, WA, USA, 22-24 June 2009. Available online: http://depts.washington.edu/uwconf/ostst2009/OSTST_book_2009_ Final.pdf (accessed on 2 April 2019).

9. Ahnert, P. National Weather Service Flash Flood Warning Program. In Proceedings of the Internacional Workshop Early Warning for flash floods, Prague, Czech Republic, 2011. Available online: http://www. preventionweb.net/files/24455_ewflashfloods.pdf (accessed on 13 May 2019).

10. Angerhofer, G. The Weather Warning System of German Weather Service Provider and Special Information for Disaster Control. In Proceedings of the Internacional Workshop Early Warning for flash floods, Prague, Czech Republic, 2011. Available online: http://www.preventionweb.net/files/24455_ewflashfloods.pdf (accessed on 13 May 2019).

11. Danhelka, J. Hydrological Forecasting and Warning in Case of Flash Flood. In Proceedings of the Internacional Workshop Early Warning for flash floods, Prague, Czech Republic, 2011. Available online: http://www. preventionweb.net/files/24455_ewflashfloods.pdf (accessed on 13 May 2019).

12. Gerard, F. State of Art with Flash Flood Early Warning and Management Capacities in France. In Proceedings of the Internacional Workshop Early Warning for flash floods, Prague, Czech Republic, 2011. Available online: http://www.preventionweb.net/files/24455_ewflashfloods.pdf (accessed on 13 May 2019).

13. Adams, T.; Pagano, T. Flood Forecasting: A Global Perspective, 1st ed; Academic Press: Cambridge, MA, USA, 2016; pp. 399-417.

14. Looper, J.P.; Vieux, B.E. An assessment of distributed flash flood forecasting accuracy using radar and rain gauge input for a physics-based distributed hydrologic model. J. Hydrol. 2012, 412, 114-132. [CrossRef]

15. Adams, T.E.; Dymond, R. The Effect of QPF on Real-Time Deterministic Hydrologic Forecast Uncertainty. J. Hydrometeor. 2019, 20, 1687-1705. [CrossRef]

16. Tao, J.; Barros, A.P. Prospects for flash flood forecasting in mountainous regions - An investigation of Tropical Storm Fay in the Southern Appalachians. J. Hydrol. 2013, 506, 69-89. [CrossRef]

17. Shamir, E.; Georgakakos, K.P.; Spencer, C.; Modrick, T.M.; Murphy, J.M.; Jubach, R. Evaluation of real-time flash flood forecasts for Haiti during the passage of Hurricane Tomas. Nat. Hazards 2013, 67, 459-482. [CrossRef]

18. Senatore, A.; Mendicino, G. Fully coupled WRF-Hydro atmospheric-hydrological modeling in a Mediterranean catchment. In Proceedings of the 1st European fully coupled Atmospheric-hydrological modeling and WRF-HYDRO users Workshop, Cosenza, Itália, 2014. Available online: http://www.ecohydrology.org/wrf-hydro2014/BookOfAbstracts.pdf (accessed on 10 June 2019).

19. Shih, D.; Chen, C.; Yeh, G. Improving our understanding of flood forecasting using earlier hydro-meteorological intelligence. J. Hydrol. 2014, 512, 470-481. [CrossRef]

20. Amengual, A.; Homar, V.; Jaume, O. Potential of a probabilistic hydrometeorological forecasting approach for the 28 September 2012 extreme flash flood in Murcia, Spain. Atmos. Res. 2015, 166, 10-23. [CrossRef]

21. Fredj, E.; Givati, A. Application of a Coupled WRF-Hydro Model for Extreme Flood Events in the Mediterranean Basins. Geophys. Res. Abstr. 2015, 17, EGU2015-7121.

22. Li, J.; Chen, Y.; Wang, H.; Qin, J.; Li, J.; Chiao, S. Extending flood forecasting lead time in a large watershed by coupling WRF QPF with a distributed hydrological model. Hydrol. Earth Syst. Sci. 2017, 21, 1279-1294. [CrossRef]

23. Silva Dias, M.A.F. Sistemas de Mesoescala e Previsão de Tempo a Curto Prazo. Rev. Bras. Meteorol. 1987, 2, 133-150.

24. Jankov, I.; Bao, J.; Neiman, P.J.; Schultz, P.J.; Yuan, H.; White, A.B. Evaluation and Comparison of Microphysical Algorithms in ARW-WRF Model Simulations of Atmospheric River Events Affecting the California Coast. J. Hydrometeor. 2009, 10, 847-870. [CrossRef]

25. Yuan, X.; Liang, X.Z.; Wood, E. WRF ensemble downscaling seasonal forecasts of China winter precipitation during 1982-2008. Clim. Dyn. 2012, 39, 2014-2058. [CrossRef] 
26. Mooney, P.A.; Mulligan, F.J.; Fealy, R. Evaluation of the sensitivity of the weather research and forecasting model to parameterization schemes for regional climates of Europe over the period 1990-95. J. Clim. 2013, 26, 1002-1017. [CrossRef]

27. Kala, J.; Andrys, J.; Lyons, T.J.; Foster, I.J.; Evans, B.J. Sensitivity of WRF to driving data and physics options on a seasonal time-scale for the southwest of Western Australia. Clim. Dyn. 2015, 44, 633-659. [CrossRef]

28. Ratnam, J.V.; Behera, S.K.; Krishnan, R.; Doi, T.; Ratna, S.B. Sensitivity of Indian summer monsoon simulation to physical parameterization schemes in the WRF model. Clim. Res. 2017, 74, 43-66. [CrossRef]

29. Attada, R.; Dasari, H.P.; Kunchala, R.K.; Langodan, S.; Niranjan Kumar, K.; Knio, O.; Hoteit, I. Evaluating Cumulus Parameterization Schemes for the Simulation of Arabian Peninsula Winter Rainfall. J. Hydrometeor. 2017, 21, 1089-1114. [CrossRef]

30. Cavalcante, M.R.G.; Barcellos, P.L.; Cataldi, M. Flash flood in the mountainous region of Rio de Janeiro state (Brazil) in 2011: Part I-Calibration watershed through hydrological SMAP model. Nat. Hazards 2020, 102, 1117-1134. [CrossRef]

31. Luz Barcellos, P.C. Desastres Naturais, Hidrometeorologia e Defesa Civil: A Sinergia entre a Ciência e a Operação para Salvar Vidas; Novas Edições Acadêmicas: Brazil, 2016.

32. Altitude Rio de Janeiro Map. Available online: https://map-of-rio-de-janeiro.com/other-maps/altitude-riode-janeiro-map (accessed on 28 July 2020).

33. Dourado, F.; Arraes, T.C.; Silva, M.F. The Mega hazard of the "Serrana" Region of Rio de Janeiro-the Causes of the Event, the Mechanisms of Mass Movements and the Spatial Distribution of Post-Disaster Reconstruction Investments. Yearbook Inst. Geosci. 2012, 35, 43-54. [CrossRef]

34. Skamarock, W.C.; Klemp, J.B.; Dudhia, J.; Gill, D.O.; Barker, D.M.; Duda, M.G.; Huang, X.; Wang, W.; Powers, J.G. A description of the Advanced Research WRF version 3. NCAR Tech. Note NCAR/TN-475+STR 2008, 113. [CrossRef]

35. Global Forecast System (GFS). Available online: https://www.ncdc.noaa.gov/data-access/model-data/modeldatasets/global-forcast-system-gfs (accessed on 29 July 2020).

36. Janjić, Z.I. The Step-Mountain Eta Coordinate Model: Further Developments of the Convection, Viscous Sublayer, and Turbulence Closure Schemes. Mon. Weather Rev. 1994, 122, 927-945. [CrossRef]

37. Grell, G.A.; Freitas, S.R. A scale and aerosol aware stochastic convective parameterization for weather and air quality modeling. Atmos. Chem. Phys. 2014, 14, 5233-5250. [CrossRef]

38. Grell, G.A. Prognostic Evaluation of Assumptions Used by Cumulus Parameterizations. Mon. Weather Rev. 1993, 121, 764-787. [CrossRef]

39. Grell, G.A.; Devenyi, D. A generalized approach to parameterizing convection combining ensemble and data assimilation techniques. Geophys. Res. Lett. 2002, 29, 38-1-38-4. [CrossRef]

40. Kain, J.S. The Kain-Fritsch Convective Parameterization: An Update. J. Appl. Meteorol. 2004, 43, $170-181$. [CrossRef]

41. Hong, S.Y.; Lim, J.O.J. The WRF single-moment 6-class microphysics scheme (WSM6). Asia Pac. J. Atmos. Sci. 2006, 42, 129-151.

42. Kessler, E. On the Distribution and Continuity of Water Substance in Atmospheric Circulations. Am. Meteorol. Soc. $1969,10,1-84$.

43. Tao, W.K.; Simpson, J.; McCumber, M. An Ice-Water Saturation Adjustment. Mon. Weather Rev. 1989, 117, 231-235. [CrossRef]

44. Aligo, E.A.; Ferrier, B.; Carley, J.R. Modified NAM Microphysics for Forecasts of Deep Convective Storms. Mon. Weather Rev. 2018, 146, 4115-4153. [CrossRef]

45. Jiménez, P.A.; Dudhia, J.; González-Rouco, J.F.; Navarro, J.; Montávez, J.P.; García-Bustamante, E. A Revised Scheme for the WRF Surface Layer Formulation. Mon. Weather Rev. 2012, 140, 898-918. [CrossRef]

46. Paulson, C.A. The mathematical representation of wind speed and temperature profiles in the unstable atmospheric surface layer. J. Appl. Meteorol. 1970, 9, 857-861. [CrossRef]

47. Hong, S.Y.; Pan, H.L. Nonlocal boundary layer vertical diffusion in a medium-range forecast model. Mon. Weather Rev. 1996, 124, 2322-2339. [CrossRef]

48. Nakanishi, M.; Niino, H. An Improved Mellor-Yamada Level-3 Model: Its Numerical Stability and Application to a Regional Prediction of Advection Fog. Bound. Layer Meteorol. 2006, 119, 397-407. [CrossRef]

49. Nakanishi, M.; Niino, H. Development of an improved turbulence closure model for the atmospheric boundary layer. J. Meteor. Soc. Jpn. 2009, 87, 895-912. [CrossRef] 
50. Dudhia, J. A multi-layer soil temperature model for MM5. In Proceedings of the sixth PSU/NCAR Mesoscale Model Users Worshop, Boulder, CO, USA, 22-24 July 1996.

51. Lopes, J.E.G.; Braga, B.P.F.; Conejo, J.G.L. SMAP-a simplifed hydrological model. In Applied Modelling in Catchment Hydrology; Singh, V.P., Ed.; Water Resources Publications: Lone Tree, CO, USA, 1982; pp. 167-176.

52. Janjić, Z.I. Comments on "Development and evaluation of a convection scheme for use in climate models". J. Atmos. Sci. 2000, 57, 3686. [CrossRef]

53. Padilha, S.F. Simulações de Eventos de Chuvas Intensas no Estado do Rio de Janeiro Usando o Modelo WRF. Master's Thesis, Universidade Federal do Rio de Janeiro, Rio de Janeiro, Brazil, 2011.

54. Ryan, B.F. On the global variation of precipitating layer clouds. Bull. Am. Meteorol. Soc. 1996, 77, 53-70. [CrossRef]

55. GATE Reports. Bull. Am. Meteorol. Soc. 1974, 55, 711-744. Available online: https://www.jstor.org/stable/ i26253638 (accessed on 6 August 2020). [CrossRef]

56. Dye, J.E.; Jones, J.J.; Winn, W.P.; Cerni, T.A.; Gardiner, B.; Lamb, D.; Pitter, R.L.; Hallett, J.; Saunders, C.P.R. Early electrification and precipitation development in a small, isolated Montana cumulonimbus. J. Geophys. Res. Atmos. 1986, 91, 1231-1247. [CrossRef]

57. Costa, A.A.; De Oliveira, J.C.; De Oliveira, J.C.P.; Sampaio, A.J.C. Microphysical Observations of Warm Cumulus Clouds in Ceará, Brazil. Atmos. Res. 2000, 54, 167-199. [CrossRef]

(C) 2020 by the authors. Licensee MDPI, Basel, Switzerland. This article is an open access article distributed under the terms and conditions of the Creative Commons Attribution (CC BY) license (http://creativecommons.org/licenses/by/4.0/). 